\title{
Changes of Immunological Profiles in Patients with Chronic Myeloid Leukemia in the Course of Treatment
}

\section{Zuzana Humlová, ${ }^{1,2}$ Hana Klamová, ${ }^{3}$ Ivana Janatková, ${ }^{2}$ Karin Malíčková, ${ }^{2}$ Petra Králíková, ${ }^{4}$ Ivan Šterzl, ${ }^{1}$ Zdeněk Roth, ${ }^{5}$ Eva Hamšíková, ${ }^{6}$ and Vladimír Vonka ${ }^{6}$}

\author{
${ }^{1}$ Department of Immunology and Microbiology, 1st Medical Faculty, Charles University, \\ and the General Teaching Hospital in Prague, Karlovo náměstí 32, 12111 Prague 2, Czech Republic \\ ${ }^{2}$ Department of Clinical Biochemistry and Laboratory Medicine, 1st Medical Faculty, \\ Charles University, Karlovo náměstí 32, 12111 Prague 2, Czech Republic \\ ${ }^{3}$ Clinical Department, Institute of Hematology and Blood Transfusion, U Nemocnice 1, 12820 Prague 2, Czech Republic \\ ${ }^{4}$ Department of Immunology, 2nd Medical Faculty, Charles University, V Úvalu 84, 15006 Prague 5, Czech Republic \\ ${ }^{5}$ Department of Biostatistics, National Institute of Health, Šrobárova 48, 10000 Prague 10, Czech Republic \\ ${ }^{6}$ Department of Experimental Virology, Institute of Hematology and Blood Transfusion, U Nemocnice 1, \\ 12820 Prague 2, Czech Republic
}

Correspondence should be addressed to Zuzana Humlová, zuzana.humlova@seznam.cz

Received 28 June 2010; Revised 15 September 2010; Accepted 20 October 2010

Academic Editor: Stuart Berzins

Copyright ( 2010 Zuzana Humlová et al. This is an open access article distributed under the Creative Commons Attribution License, which permits unrestricted use, distribution, and reproduction in any medium, provided the original work is properly cited.

\begin{abstract}
In the previous paper of ours we compared, prior to start any treatment, a number of immunological parameters in 24 chronic myeloid leukemia patients with the same number of healthy subjects matched by age and sex. We found significant differences in the levels of immunoglobulins, the $\mathrm{C} 4$ component of complement, the C-reactive protein, interleukin 6, the composition of lymphocyte population and the production of some cytokines by stimulated CD3+ cells. Eleven of these patients were followed longitudinally. After treatment with hydroxyurea, interferon alpha, imatinib mesylate and dasatinib, or various combinations thereof, hematological remission was achieved in all patients and complete cytogenetic remission in nine of them. There was a nearly general tendency towards normalization of the abnormalities observed in the patients at their enrollment.
\end{abstract}

\section{Introduction}

The treatment of chronic myeloid leukemia (CML) now offers several options from which to choose. Hydroxyurea (HU) was introduced in the late 1960s and for decades remained the mainstay of palliation in CML. However, $\mathrm{HU}$ does not induce cytogenetic remissions in a significant percentage of patients nor does it markedly change the natural history of the disease. The adverse effects include gastrointestinal problems and cutaneous defects as leg ulcers [1], hyperpigmentation of the skin and nails, a lichen planuslike eruption, lupus erythematosus, and dermatomyositislike eruption [2]. The first observational reports on a cytoreductive effect of interferon $\alpha$ (IFN $\alpha$ ) in CML patients date back to 1980 s, when IFN $\alpha$ treatment was introduced at the M.D. Anderson Cancer Center, Houston, Texas [3, 4]. IFN $\alpha$ induces durable major and even complete cytogenetic remissions (CCR) persisting for months, sometimes even for years [5]. IFN $\alpha$ not only mediates antileukemic responses via induction of T-cell immunity $[6,7]$, but it also promotes humoral immunity against CML antigens [8]. Some parameters of innate immunity, which apparently plays a role in anticancer immunity, are also favorably influenced by IFN $\alpha$ $[9,10]$. This might elucidate the efficacy of IFN $\alpha$ treatment in vivo by orchestrating a network of immune cells rather than by the activation of individual populations. Other mechanisms involved in modulating the course of the disease by IFN $\alpha$ are connected with its antiproliferative effect. However, long-term treatment with IFN $\alpha$ can also produce or exacerbate immune-mediated complications $[11,12]$, such as 
cutaneous vasculitis, hemolytic anemia, thyroid gland disorders, immune-mediated thrombocytopenia, nephrotoxicity, pemphigus foliaceus, rheumatoid arthritis, systemic lupus erythematosus, and even heart dysfunction based probably on immune mechanisms [11]. A revolution into therapy of CML has been brought by the introduction of the so-called targeted drugs. The first of these disease-tailored products has been imatinib mesylate (IM) which blocks the ATPbinding pocket on the BCR-ABL tyrosine-kinase and thus prevents the activation of this enzyme which plays the key role in the pathogenesis of CML [13]. IM has been reported to have induced CCR in 74\% of the newly diagnosed patients and is also active in patients previously treated with INF $\alpha$ [14]. According to a recent update, a five-year survival has been achieved in nearly $90 \%$ of CML patients [15]. However, in a portion of patients, resistance to the drug develops mostly due to the mutations in the enzyme catalytic domain [16] or as a consequence of the amplification of the bcrabl fusion gene [17]. To deal with the problem, a new generation of targeted drugs is being introduced and some of its representatives are already in clinical use, for example, dasatinib [18] or nilotinib [19].

Still, neither of these drugs can cure the disease most probably due to their failure to hit the quiescent cancer stem cells. When the treatment is interrupted, the disease relapses. Many oncohematologists believe that the problem of curing CML might be unriddled by supplementing the chemotherapy with immunotherapeutic approaches. A mathematical model has been constructed suggesting that immunotherapeutic intervention tailored to the clinical condition and the underlying immune status of the patient may result in the cure of CML [20].

Although the role of immune reactions in the course of CML has been demonstrated beyond reasonable doubt, the first vaccine trials reported in the past 10 years have not been particularly successful (for review see [21]). We are of the opinion that to achieve the immunization goal it will be necessary to augment our present knowledge on the immunology of CML patients and that very likely this will lead to appreciable progress in the future immunotherapeutic undertakings.

It was the purpose of the present study to construct immunological profiles of CML patients by testing several parameters of their innate immunity early after diagnosis, that is, prior to the start of any therapy and then to follow the influence of different therapeutic regimens on these parameters and the association of their changes with the clinical condition. In a previous paper of ours [22], representing the first part of the present study, we reported the findings obtained in $24 \mathrm{CML}$ patients before the start of any therapy and in the same number of matched healthy subjects. We found a number of deviations from the norm in the immune reactivity of CML patients and significant differences between the patients' and control groups. The main differences encountered in the patients were represented by increased levels of IgA $(P<.02)$, the C4 component of complement $(P<.05)$, C-reactive protein $(\mathrm{CRP})(P<.02)$, and interleukin 6 (IL-6) $(P<.0005)$. Furthermore, a highly significantly decreased production of interleukin-2 (IL-2) $(P<.0001)$ and tumor necrosis factor $\alpha(\mathrm{TNF} \alpha)(P<.001)$ in stimulated CD3+ lymphocytes and a decreased phagocytosis of killed $E$. coli by polymorphonuclears $(P<.0001)$ were observed. In spite of the frequency of these aberrations, no consistent pattern which might be characteristic for CML was revealed. In the subsequent follow-up we unfortunately met considerable difficulties. First of all, we lost the majority of patients (13 of 24) for various reasons. Several of them were transplanted, a few moved out of Prague or even left the country, and some simply lost their interest in participating in the study. Another complication resulted from the dramatic progress in the therapy of CML due to the introduction of a new generation of highly effective and relatively very well-tolerated new drugs (see above). From ethical reasons, it was necessary to substitute these new drugs for the older ones. It followed that most of the patients were treated with more than one drug.

\section{Materials and Methods}

2.1. Patients. The basic data on 11 patients enrolled at the time of diagnosis (i.e., before starting any therapy) who remained in the study throughout are shown in Table 1. The group consisted of 5 males and 6 females, their median age was 48 years, and their age range from 33 to 62 years. The follow-up lasted for 44 to 58 months. All patients were treated either with imatinib mesylate (IM) or dasatinib (DS), but not in all of them were these drugs used as the starting therapy. In six patients, administration of tyrosine-kinase inhibitors (TKI) was preceded by interferon $\alpha(\operatorname{IFN} \alpha)$ treatment and in five patients the administration of IFN $\alpha$ followed the initial treatment with hydroxyurea (HU). In two patients, HU was given prior to IM treatment. Hematological remission was achieved in all patients and complete cytogenetic remission (CCR) was achieved in nine of them in the course of the observation period. This was associated with the decrease of lymphocyte count in nearly all the patients. The only exception was patient no. 6 , with leukopenia prior to the start of the therapy, in whom the remission was associated with an increase of lymphocyte count up to the norm. At the end of the observation period, thrombocyte count was below the level of $450 \times 10^{9} / \mathrm{L}$ in all patients. In eight of the patients the therapy was not associated with any complication. Patient no. 1, who had originally been treated with HU and who had developed symptoms of immunodeficiency (neutropenia, aphthous stomatitis, repeated infections of the upper and lower respiratory tract) in the course of the observation period, underwent a supportive therapy with growth factors (Neupogen $300 \mu \mathrm{G} /$ week) and immunoglobulins (Pasteurised Human Immunoglobulin Grifols $16 \% 5 \mathrm{~mL}$ i.m. once a week for 3 weeks). Moreover, erythematous eruptions diagnosed as erythema nodosum vasculitis developed on her feet. As an additional therapy, she received routine anti-inflammatory drugs and local corticosteroids. In this patient CCR was not achieved in spite of the IM dose having been raised to $600 \mathrm{mg}$ per day. 
In patients nos. 6 and 7, laboratory tests revealed autoantibodies against thyroidal peroxidase and thyreoglobulin without clinical signs of hyper- or hypothyroidism. After switching to IM or DS, the laboratory findings normalized (see the Results section).

2.2. Drugs Used. Patients were treated as specified in Table 1. LITALIR (HU-Hydroxycarbamidum 500 mg, Bristol-Myers Squibb, Ltd, Prague, Czech Republic), ROFERON-A (INF- $\alpha$ Interferon $\alpha$ 2a $18 \mathrm{MIU} / 0.6 \mathrm{~mL}$ inj. sol., Roche, Ltd, Prague, Czech Republic), Glivec (imatinib-mesylate Glivec, $478 \mathrm{mg}$, Novartis Europharm Ltd., Horsham, West Sussex, Great Britain), and SPRYCEL (Dasatinib $100 \mathrm{mg}$, Bristol-Myers Squibb Pharma Eeig, Uxbridge Business Park, Sanderson Road, Uxbridge, UK) were used. The dosage of the drugs administered is indicated in Table 1.

2.3. Blood Samplings. Before sampling, written Informed Consent was obtained from all patients and the study was approved by the Ethical Committees of the institutions concerned. In addition to samples taken for routine hematological and biochemical testing, materials for immunological assays were obtained from each subject. The first samples were taken prior to the start of any therapy. Subsequent samples were usually collected before the change in therapy. The intervals varied (with one exception, patients no. 8) from 6 to 30 months. The blood samples were distributed into tubes purchased from BD Vacutainer Systems, Belliver Industrial Estate, Plymouth, UK, as follows: (i) $7 \mathrm{~mL}$ of blood were taken into $\mathrm{Z}$ tubes, coagulated, and the serum was used for humoral immunity tests; (ii) $2 \mathrm{~mL}$ of blood were mixed with EDTA for immunophenotypic analysis; (iii) $2 \mathrm{~mL}$ of the whole blood were mixed with sodium heparine for the measuring of intracellular cytokines. The materials were tested (see below) immediately after arrival at the laboratory, except the viral antibodies, CRP and IL-6 (see below) for which all sera were tested simultaneously. Portions of the materials were preserved for further tests. Sera were stored at $-20^{\circ} \mathrm{C}$ and leukocyte suspensions were stored in liquid nitrogen for possible future tests.

2.4. Immunoglobulins. The levels of the total IgG, of the IgG subclasses, of IgA, and IgM were measured by nephelometry as described previously [22]. The standard laboratory referential ranges are 6.9-14.0 g/L for IgG, 4.9-11.4 g / L for IgG1, 1.5-6.4 g/L for IgG2, 0.2-1.1 g/L for IgG3, 0.08-1.4 g/L for IgG4, 0.7-3.7 g/L for IgA, and $0.34-2.4 \mathrm{~g} / \mathrm{L}$ for IgM.

2.5. Autoantibodies. Antibodies against thyroidal peroxidase (ATPOAb), thyreoglobulin (ATGAb), nucleus (ANAb), mitochondria (AMAb), smooth muscles (ASMAb), cytoplasm of neutrophils (ANCAb), and endomysium (AE-GAb, AE$\mathrm{AAb} ; \mathrm{G}$ refers to IgG and A refers to IgA antibody, resp.) were detected by indirect immunofluorescence as described previously [22]. We have also tested the presence of antidesmosomal antibodies (ADESAb). Only the presence or absence of antibodies was monitored, not their titers.
2.6. Complement. The levels of the C3 and C4 components of complement were measured by nephelometry as described previously [22]. The standard laboratory referential ranges are $0.75-1.4 \mathrm{~g} / \mathrm{L}$ for $\mathrm{C} 3$ and $0.10-0.34 \mathrm{~g} / \mathrm{L}$ for C4.

2.7. C-Reactive Protein. The levels of the C-reactive protein (CRP) were measured by nephelometry as described previously [22]. The standard laboratory reference range is $0.00-$ $5.0 \mathrm{mg} / \mathrm{L}$.

2.8. Interleukin-6. For the determination of interleukin 6 (IL-6), the quantitative sandwich enzyme immunoassay techniques was used as described previously [22]. The standard laboratory referential range is $3.13-12.5 \mu \mathrm{g} / \mathrm{L}$.

2.9. Subpopulations of Lymphocytes. Immunophenotypic analysis of lymphocytes was performed using monoclonal antibodies directed against the following human surface antigens: CD3, CD4, CD8, CD19, CD16, and CD56 by flow cytometry as described previously [22]. The sum of cells stained with CD4, CD8, CD19, and CD16-CD56 antibodies was considered $100 \%$. The standard laboratory referential ranges are: $59 \%-84 \%$ for CD3+, 25\%-59\% for CD4+, 19\%$48 \%$ for CD $8+, 6 \%-22 \%$ for CD $19+, 6 \%-30 \%$ for CD $16+$, CD56+ cells.

2.10. Intracellular Cytokine Production by Stimulated CD3+ Cells. Intracellular production of interleukin-2 (IL-2) interleukin-4 (IL-4), tumor necrosis alpha (TNF $\alpha)$, and interferon gamma (INF $\gamma$ ) in CD3+ cells stimulated by the mixture of brefeldinA and phorbol-12-myristate-13-acetate was monitored by flow cytometry as described previously [22]. The figures shown in the Results section indicate the percentages of CD3+ producing the individual cytokines.

\subsection{Antibodies against Herpesviruses and Human Papillo-} maviruses. Antibodies were determined against the following herpesviruses: the herpes simplex virus type 1 and type 2 (HSV 1 and 2, IgG and IgM), the varicella-zoster virus (VZV, IgG and $\operatorname{IgM}$ ), the human cytomegalovirus (CMV, IgG and $\operatorname{IgM}$ ) and the EB virus (EBV, IgG and IgM against the virus capsid antigen [VCA], IgG against the virus nuclear antigen [EBNA1] and against the early antigens [EA R+D]). The following commercial kits were used: ETI-HSVK-G-1/2 and ETI-HSVK-M-1/2 (DiaSorin S.p.A., Italy) for the detection of HSV $1 / 2$ IgG and IgM antibody, respectively; ETICYTOK-G Plus and ETI-CYTOK-M REV Plus (DiaSorin S.p.A., Italy ) for the detection of CMV IgG and IgM antibody, respectively; VZV IgG and VZV IgM (Nova Tec, Immunodiagnostica, GmbH Germany) for the detection of VZV IgG and IgM antibody, respectively; ETI-EBV VCA-G and ETI-EBV-VCA-M-Rev (DiaSorin S.p.A., Italy) for the detection of EBV VCA IgG and IgM antibody, respectively; ETI-EBNA-G (DiaSorin S.p.A., Italy) for the detection of EBV EBNA IgG antibody; and ETI-EA-G (DiaSorin S.p.A., Italy) for the detection of EBV EA IgG antibody. In addition, antibodies to six types of human papillomaviruses (HPV), namely, types $6,11,16,18,31$, and 33 were determined 
Table 1: Patients followed.

\begin{tabular}{|c|c|c|c|c|c|c|c|c|c|c|c|}
\hline \multirow[t]{2}{*}{ No. } & \multirow[t]{2}{*}{ Gender } & \multirow[t]{2}{*}{$\mathrm{Age}^{1}$} & \multicolumn{2}{|c|}{ Treatment } & \multicolumn{7}{|c|}{ Hematologic } \\
\hline & & & $\mathrm{Mo}^{2}$ & Drug & Dosage/d & $\mathrm{WBC} \times 10^{9} / \mathrm{L}$ & Lympho $\times 10^{9} / \mathrm{L}$ & $\mathrm{Hb}(\mathrm{gr} / \mathrm{L})$ & $\operatorname{Trc} \times 10^{9} / \mathrm{L}$ & $\mathrm{HR}^{3}$ & $\mathrm{CCR}^{3}$ \\
\hline \multirow{7}{*}{ (1) } & \multirow{7}{*}{$\mathrm{F}$} & \multirow{7}{*}{55} & 0 & $\mathrm{dg}, \mathrm{HU}$ & $2000 \mathrm{mg}$ & 302.6 & 4.60 & 89 & 413 & \multirow{7}{*}{19} & \multirow{7}{*}{ No } \\
\hline & & & 8 & IFN & $5 \mathrm{MIU}$ & 16.2 & 1.45 & 130 & 188 & & \\
\hline & & & 16 & IFN & $5 \mathrm{MIU}$ & 69.0 & 3.43 & 131 & 442 & & \\
\hline & & & 22 & IM & $400 \mathrm{mg}$ & 10.5 & 2.86 & 124 & 399 & & \\
\hline & & & 27 & IM & $400 \mathrm{mg}$ & 7.4 & 1.93 & 120 & 505 & & \\
\hline & & & 39 & IM & $600 \mathrm{mg}$ & 4.0 & 1.11 & 120 & 175 & & \\
\hline & & & 58 & DS & $100 \mathrm{mg}$ & 2.1 & 0.89 & 119 & 139 & & \\
\hline \multirow{7}{*}{ (2) } & \multirow{7}{*}{$\mathrm{F}$} & \multirow{7}{*}{62} & 0 & dg, HU & $2500 \mathrm{mg}$ & 120.0 & 3.54 & 132 & 226 & \multirow{7}{*}{6} & \multirow{7}{*}{19} \\
\hline & & & 6 & IFN & $3 \mathrm{MIU}$ & 4.7 & 1.49 & 151 & 163 & & \\
\hline & & & 14 & IFN & $3 \mathrm{MIU}$ & 5.1 & 1.20 & 131 & 352 & & \\
\hline & & & 15 & IFN & $5 \mathrm{MIU}$ & 5.8 & 0.91 & 140 & 356 & & \\
\hline & & & 25 & IM & $400 \mathrm{mg}$ & 3.2 & 1.12 & 138 & 157 & & \\
\hline & & & 43 & IM & $400 \mathrm{mg}$ & 7.0 & 1.38 & 130 & 430 & & \\
\hline & & & 56 & IM & $400 \mathrm{mg}$ & 9.3 & 1.61 & 130 & 648 & & \\
\hline \multirow{6}{*}{ (3) } & \multirow{6}{*}{ M } & \multirow{6}{*}{40} & 0 & $\mathrm{dg}, \mathrm{HU}$ & $3000 \mathrm{mg}$ & 21.9 & 2.07 & 168 & 327 & \multirow{6}{*}{8} & \multirow{6}{*}{26} \\
\hline & & & 7 & IFN & $3 \mathrm{MIU}$ & 8.1 & 1.08 & 163 & 262 & & \\
\hline & & & 15 & IFN & $5 \mathrm{MIU}$ & 3.1 & 0.85 & 160 & 125 & & \\
\hline & & & 26 & IM & $400 \mathrm{mg}$ & 4.2 & 1.10 & 146 & 246 & & \\
\hline & & & 43 & IM & $400 \mathrm{mg}$ & 4.5 & 1.37 & 147 & 209 & & \\
\hline & & & 58 & IM & $400 \mathrm{mg}$ & 3.9 & 1.01 & 158 & 210 & & \\
\hline \multirow{5}{*}{ (4) } & \multirow{5}{*}{ M } & & 0 & $\mathrm{dg}, \mathrm{HU}$ & $2000 \mathrm{mg}$ & 198.5 & 5.06 & 110 & 550 & & \\
\hline & & & 6 & IFN & $3 \mathrm{MIU}$ & 3.4 & 0.86 & 132 & 115 & & \\
\hline & & 60 & 12 & IFN & $5 \mathrm{MIU}$ & 3.4 & 1.21 & 137 & 152 & 6 & 36 \\
\hline & & & 42 & IM & $400 \mathrm{mg}$ & 5.5 & 1.52 & 131 & 301 & & \\
\hline & & & 56 & IM & $400 \mathrm{mg}$ & 3.5 & 1.56 & 136 & 311 & & \\
\hline & & & 0 & dg, HU & $2500 \mathrm{mg}$ & 99.7 & 5.91 & 142 & 169 & & \\
\hline & & & 6 & $\mathrm{HU}$ & $2000 \mathrm{mg}$ & 9.9 & 3.56 & 145 & 151 & & \\
\hline (5) & $\mathrm{M}$ & 33 & 9 & IFN & $3 \mathrm{MIU}$ & 47.8 & 3.12 & 137 & 102 & 2 & 40 \\
\hline & & & 40 & IM & $400 \mathrm{mg}$ & 4.3 & 1.69 & 142 & 202 & & \\
\hline & & & 53 & IM & $400 \mathrm{mg}$ & 5.5 & 2.01 & 140 & 258 & & \\
\hline & & & 58 & IM & $400 \mathrm{mg}$ & 6.6 & 1.88 & 136 & 266 & & \\
\hline & & & 0 & $\mathrm{dg}, \mathrm{IFN}$ & $3 \mathrm{MIU}$ & 107.5 & 0.48 & 117 & 276 & & \\
\hline & & & 10 & IFN & $3 \mathrm{MIU}$ & 4.4 & 0.76 & 101 & 182 & & \\
\hline (6) & F & 35 & 12 & IM & $400 \mathrm{mg}$ & 2.8 & 1.12 & 102 & 145 & 2 & 35 \\
\hline & & & 36 & DS & $100 \mathrm{mg}$ & 2.9 & 1.61 & 89 & 233 & & \\
\hline & & & 48 & DS & $100 \mathrm{mg}$ & 2.8 & 1.83 & 89 & 331 & & \\
\hline & & & 0 & $\mathrm{dg}, \mathrm{HU}$ & $2000 \mathrm{mg}$ & 16.4 & 4.86 & 136 & 595 & & \\
\hline & & & 7 & $\mathrm{HU}$ & $2000 \mathrm{mg}$ & 4.5 & 5.71 & 137 & 532 & & \\
\hline (7) & $\mathrm{M}$ & 54 & 20 & $\mathrm{HU}$ & $1000 \mathrm{mg}$ & 5.5 & 3.21 & 134 & 209 & 11 & 38 \\
\hline & & & 34 & IM & $400 \mathrm{mg}$ & 6.9 & 1.23 & 134 & 206 & & \\
\hline & & & 47 & IM & $400 \mathrm{mg}$ & 6.8 & 2.19 & 132 & 236 & & \\
\hline
\end{tabular}


TABLE 1: Continued.

\begin{tabular}{|c|c|c|c|c|c|c|c|c|c|c|c|}
\hline \multirow[t]{2}{*}{ No. } & \multirow[t]{2}{*}{ Gender } & \multirow[t]{2}{*}{ Age $^{1}$} & \multicolumn{2}{|c|}{ Treatment } & \multicolumn{7}{|c|}{ Hematologic } \\
\hline & & & $\mathrm{Mo}^{2}$ & Drug & Dosage/d & $\mathrm{WBC} \times 10^{9} / \mathrm{L}$ & Lympho $\times 10^{9} / \mathrm{L}$ & $\mathrm{Hb}(\mathrm{gr} / \mathrm{L})$ & $\operatorname{Trc} \times 10^{9} / \mathrm{L}$ & $\mathrm{HR}^{3}$ & $\mathrm{CCR}^{3}$ \\
\hline \multirow{6}{*}{$(8)$} & \multirow{6}{*}{$\mathrm{F}$} & \multirow{6}{*}{43} & 0 & $\mathrm{dg}, \mathrm{IM}$ & $400 \mathrm{mg}$ & 26.9 & 4.05 & 144 & 464 & \multirow{6}{*}{2} & \multirow{6}{*}{17} \\
\hline & & & 2 & IM & $400 \mathrm{mg}$ & 8.3 & 1.66 & 129 & 228 & & \\
\hline & & & 9 & IM & $400 \mathrm{mg}$ & 6.0 & 1.76 & 123 & 185 & & \\
\hline & & & 17 & IM & $400 \mathrm{mg}$ & 7.5 & 1.26 & 126 & 207 & & \\
\hline & & & 31 & IM & $300 \mathrm{mg}$ & 7.6 & 1.73 & 120 & 239 & & \\
\hline & & & 45 & IM & $300 \mathrm{mg}$ & 8.3 & 1.45 & 125 & 315 & & \\
\hline \multirow{3}{*}{ (9) } & \multirow{3}{*}{ M } & \multirow{3}{*}{48} & 0 & $\mathrm{dg}, \mathrm{IM}$ & $400 \mathrm{mg}$ & 439.2 & 6.16 & 81 & 184 & \multirow{3}{*}{7} & \multirow{3}{*}{ No } \\
\hline & & & 30 & $\mathrm{IM}$ & $400 \mathrm{mg}$ & 4.4 & 1.96 & 150 & 117 & & \\
\hline & & & 44 & IM & $400 \mathrm{mg}$ & 5.4 & 1.41 & 149 & 112 & & \\
\hline \multirow{4}{*}{$(10)$} & \multirow{4}{*}{$\mathrm{F}$} & \multirow{4}{*}{38} & 0 & $\mathrm{dg}, \mathrm{IM}$ & $400 \mathrm{mg}$ & 328.6 & 1.81 & 88 & 614 & \multirow{4}{*}{5} & \multirow{4}{*}{27} \\
\hline & & & 7 & IM & $400 \mathrm{mg}$ & 3.0 & 1.32 & 121 & 200 & & \\
\hline & & & 28 & IM & $400 \mathrm{mg}$ & 3.3 & 1.10 & 94 & 212 & & \\
\hline & & & 36 & IM & $400 \mathrm{mg}$ & 4.9 & 0.98 & 103 & 236 & & \\
\hline \multirow{3}{*}{ (11) } & \multirow{3}{*}{$\mathrm{F}$} & \multirow{3}{*}{61} & 0 & $\mathrm{dg}, \mathrm{HU}$ & $2000 \mathrm{mg}$ & 16.8 & 5.31 & 109 & 1895 & \multirow{3}{*}{4} & \multirow{3}{*}{25} \\
\hline & & & 29 & DS & $100 \mathrm{mg}$ & 5.8 & 2.02 & 100 & 519 & & \\
\hline & & & 52 & DS & $100 \mathrm{mg}$ & 5.4 & 2.75 & 104 & 249 & & \\
\hline
\end{tabular}

${ }^{1}$ Age at enrollment; ${ }^{2} \mathrm{Mo}$ : month; WBC: white blood cell count; Hb: hemoglobin; and Trc, thrombocyte count; HU: hydroxyurea; IFN: interferon-alpha 2a; IM: imatinib mesylate; DS: dasatinib; MIU, Millions International Units. ${ }^{3}$ The figure indicates month after diagnosis at which HR or CCR was first observed; "no" means that CCR was not achieved.

Notes: Patient no. 1 developed vasculitis (erythema nodosum), neutropenia which was subsequently treated with growth factors and immunoglobulins. Patients 6 and 7 had laboratory tests positive for autoimmune thyroiditis without any clinical manifestations.

Patient no. 11 decided to undergo homeopathic therapy and self-therapy with HU and was out of the evidence for some time. At the indicated interval, DS therapy was started because of pathological findings both in peripheral blood and bone marrow.

using ELISA using virus-like particles as antigen as described previously [23]. Sera were diluted according to corresponding manufacturer recommendation, in case of anti-HPV antibodies $1: 25$. All samples originating from the same patient were tested simultaneously on one microplate.

2.12. Statistical Methods. In individual patients, Spearman's correlation coefficient was used for quantifying the monotony of trend in time of the measured items. The statistical difference $P$ for the deviation from zero was calculated. When analyzing the hematologic findings for the whole group of patients, the data transformed to logarithms were analyzed by covariance analysis testing for differences among patients and the common linear regression onto the time of treatment. The linear function was used as a basic component of the experienced time trend. For comparison of the relative percentage distribution of different lymphocyte populations in the first and last samples available, $\chi^{2}$ test was used. For evaluation of the production of cytokines by stimulated CD3+ cells, the mean ratio of the last and first samples available was tested by One Sample Student $t$-test for difference from 1. $P$-values have not been adjusted for multiple comparisons.

\section{Results}

3.1. Immunoglobulins Levels. The results of measuring the immunoglobulins levels are summarized in Table 2. Nearly generally, there was a tendency to a decrease of their levels. The decrease of total IgG for the whole group was just on the brink of statistical significance $(P=.05)$. In two patients (nos. 2 and 7) the IgG levels dropped below the norm. On the other hand, a marked increase of IgGs was observed in one patient (No. 6, treated gradually with IFN $\alpha$, IM and DS) who had had the lowest level of total IgG and pathologically low levels of IgG1, IgG2, IgG3 and IgG4 in her pretreatment serum. The treatment resulted in their restoration up to the norm. It may be of interest that in this patient the hemoglobin level dropped in the course of the observation period (see Table 1). The most frequent changes were in the IgM levels. Their slight or moderate decrease was observed in 9 patients and usually it was most marked after treatment with IM. The decrease of IgM levels for the whole group was significant $(P=.011)$. Changes in IgA levels were seen less frequently. Its levels dropped significantly with time in only one patient (no. 2) and increased in other three (nos. 6,9 and 11). The first one of these was the already mentioned patient no. 6 with an increase in all subclasses of IgG. It is noteworthy that throughout the observation period the changes in this particular patient were not associated with any marked variation in the IgM level.

3.2. Presence of Autoantibodies. The presence of autoantibodies is shown in Table 3. Again, no consistent pattern is apparent. Autoantibodies, which had been present in the pretreatment sera of only three patients (twice against TPO 
TABLE 2: Imunoglobulins.

\begin{tabular}{|c|c|c|c|c|c|c|c|c|}
\hline No. & Therapy & $\operatorname{IgG}$ & IgG1 & IgG2 & IgG3 & IgG4 & $\operatorname{IgA}$ & $\operatorname{IgM}$ \\
\hline \multirow{7}{*}{ (1) } & dg, HU & 10.60 & 6.73 & 4.29 & 0.686 & 0.526 & 2.16 & 1.65 \\
\hline & IFN & 11.10 & 6.14 & 3.74 & 0.767 & 0.364 & 1.95 & 1.50 \\
\hline & IFN & 9.30 & 5.97 & 3.22 & 0.530 & 0.250 & 1.93 & 1.56 \\
\hline & IM & 12.30 & 8.90 & 3.99 & 0.709 & 0.119 & 2.74 & 1.91 \\
\hline & IM & 9.40 & 6.82 & 3.34 & 0.575 & 0.157 & 2.17 & 1.61 \\
\hline & IM & 11.30 & 6.14 & 4.21 & 0.687 & 0.193 & 2.92 & 1.54 \\
\hline & DS & 11.40 & 6.70 & 3.81 & 0.907 & 0.253 & 2.73 & 1.29 \\
\hline \multirow{7}{*}{ (2) } & dg, HU & 10.00 & 6.72 & 3.34 & 0.418 & 0.460 & 2.31 & 0.76 \\
\hline & IFN & 8.58 & 5.00 & 3.34 & 0.353 & 0.339 & 2.12 & 0.72 \\
\hline & IFN & 8.53 & 5.64 & 3.00 & 0.358 & 0.397 & 1.68 & 0.45 \\
\hline & IFN & 9.39 & 4.50 & 3.13 & 0.320 & 0.247 & 1.50 & 0.40 \\
\hline & IM & 8.49 & 4.41 & 2.75 & 0.292 & 0.259 & 1.59 & 0.33 \\
\hline & IM & 6.78 & 3.98 & 2.18 & 0.312 & 0.179 & 1.35 & 0.20 \\
\hline & IM & $6.41^{* *}$ & $3.91^{* *}$ & $2.24^{* *}$ & $2.92^{* *}$ & $1.52^{* *}$ & $1.23^{* *}$ & $0.23^{* *}$ \\
\hline \multirow{6}{*}{ (3) } & dg, HU & 10.00 & 6.41 & 3.03 & 0.225 & 0.079 & 1.79 & 1.44 \\
\hline & IFN & 9.19 & 5.83 & 2.74 & 0.196 & 0.082 & 1.66 & 0.83 \\
\hline & IFN & 10.80 & 6.33 & 3.28 & 0.239 & 0.058 & 1.74 & 0.87 \\
\hline & IM & 9.08 & 5.71 & 3.23 & 0.190 & 0.091 & 1.66 & 0.38 \\
\hline & IM & 8.72 & 5.04 & 2.68 & 0.248 & 0.083 & 1.73 & 0.54 \\
\hline & IM & 9.41 & $5.18^{*}$ & 3.35 & 0.213 & 0.065 & 1.78 & 0.47 \\
\hline \multirow{5}{*}{ (4) } & dg, HU & 11.60 & 7.79 & 3.94 & 0.666 & 0.833 & 1.86 & 0.94 \\
\hline & IFN & 13.00 & 8.44 & 4.05 & 0.686 & 0.303 & 1.62 & 1.18 \\
\hline & IFN & 13.60 & 10.40 & 3.34 & 0.637 & 0.270 & 1.80 & 0.98 \\
\hline & IM & 10.90 & 6.51 & 3.10 & 0.541 & 0.231 & 1.62 & 0.58 \\
\hline & IM & 10.90 & 6.98 & 3.34 & 0.613 & $0.209^{* *}$ & 1.84 & 0.66 \\
\hline \multirow{6}{*}{ (5) } & dg, HU & 10.40 & 6.29 & 3.04 & 0.248 & 0.133 & 1.59 & 1.76 \\
\hline & $\mathrm{HU}$ & 10.20 & 7.40 & 3.03 & 0.158 & 0.066 & 1.98 & 1.20 \\
\hline & IFN & 9.35 & 6.20 & 2.97 & 0.195 & 0.142 & 1.61 & 1.31 \\
\hline & IM & 9.21 & 5.01 & 2.82 & 0.236 & 0.097 & 1.83 & 1.13 \\
\hline & IM & 9.81 & 5.33 & 3.16 & 0.226 & 0.082 & 1.93 & 1.12 \\
\hline & IM & $9.11^{*}$ & 6.77 & 2.62 & 0.605 & 0.081 & 1.95 & $1.06^{* *}$ \\
\hline \multirow{5}{*}{ (6) } & dg, IFN & 8.05 & 5.63 & 1.27 & 0.135 & 0.073 & 1.17 & 1.10 \\
\hline & IFN & 11.30 & n.t. ${ }^{\mathrm{a}}$ & n.t. & n.t. & n.t. & 1.39 & 1.29 \\
\hline & IM & 12.00 & n.t. & n.t. & n.t. & n.t. & 1.58 & 1.41 \\
\hline & DS & 17.90 & 12.70 & 1.75 & 0.611 & 0.152 & 2.07 & 0.79 \\
\hline & DS & $13.6^{*}$ & 11.20 & $2.17^{* *}$ & 0.416 & $0.188^{* *}$ & $2.26^{* *}$ & 1.18 \\
\hline \multirow{5}{*}{ (7) } & dg, HU & 8.92 & 4.60 & 4.01 & 0.388 & 0.610 & 1.22 & 0.95 \\
\hline & $\mathrm{HU}$ & 8.79 & 4.45 & 3.95 & 0.337 & 0.797 & 1.30 & 0.76 \\
\hline & $\mathrm{HU}$ & 8.76 & 3.81 & 4.11 & 0.266 & 0.702 & 1.34 & 0.51 \\
\hline & IM & 6.08 & 2.89 & 2.72 & 0.262 & 0.507 & 0.99 & 0.32 \\
\hline & IM & $6.63^{*}$ & $31.4^{*}$ & 2.90 & 0.303 & 0.425 & 0.93 & $0.36^{*}$ \\
\hline \multirow{6}{*}{ (8) } & $\mathrm{dg}, \mathrm{IM}$ & 12.60 & 9.51 & 3.53 & 0.080 & n.t. & 1.49 & 0.97 \\
\hline & IM & 11.60 & 8.81 & 2.73 & 0.083 & 0.320 & 1.75 & 0.79 \\
\hline & IM & 12.20 & 7.43 & 2.74 & 0.087 & 0.276 & 1.84 & 0.57 \\
\hline & IM & 12.60 & 7.64 & 3.21 & 0.087 & 0.188 & 1.67 & 0.63 \\
\hline & IM & 12.60 & 9.30 & 3.26 & 0.094 & 0.432 & 1.94 & 0.74 \\
\hline & IM & 11.70 & 7.41 & 2.95 & 0.072 & 0.273 & 1.93 & 0.72 \\
\hline
\end{tabular}


Table 2: Continued.

\begin{tabular}{ccccccccc}
\hline No. & Therapy & IgG & IgG1 & IgG2 & IgG3 & IgG4 & IgA & IgM \\
\hline \multirow{4}{*}{$(9)$} & $\mathrm{dg}, \mathrm{IM}$ & 10.60 & 7.58 & 3.41 & 0.523 & 0.697 & 1.31 & 1.11 \\
& $\mathrm{IM}$ & 9.43 & 5.36 & 3.41 & 0.480 & 0.790 & 1.47 & 1.11 \\
& $\mathrm{IM}$ & 9.53 & 5.90 & 3.95 & $0.479^{* *}$ & 0.738 & $1.81^{* *}$ & 1.32 \\
\hline \multirow{4}{*}{$(10)$} & $\mathrm{dg}, \mathrm{IM}$ & 13.50 & 8.46 & 4.93 & 0.231 & 2.180 & 1.04 & 1.61 \\
& $\mathrm{IM}$ & 14.20 & 7.63 & 5.63 & 0.211 & 1.970 & 1.28 & 1.60 \\
& $\mathrm{IM}$ & 12.10 & 7.49 & 4.49 & 0.262 & 1.200 & 1.04 & 1.39 \\
& $\mathrm{IM}$ & 12.20 & $6.63^{* *}$ & 4.51 & 0.232 & 1.340 & 1.15 & 1.41 \\
\hline \multirow{3}{*}{$(11)$} & $\mathrm{dg}, \mathrm{HU}$ & 12.00 & 6.21 & 5.66 & 0.231 & 0.146 & 0.88 & 0.67 \\
& $\mathrm{DS}$ & 11.50 & 5.97 & 5.63 & 0.271 & 0.085 & 0.91 & 0.45 \\
& $\mathrm{DS}$ & 12.40 & 8.12 & $3.50^{* *}$ & $0.677^{* *}$ & $0.080^{* *}$ & $1.02^{* *}$ & $0.32^{* *}$ \\
\hline
\end{tabular}

a n.t.: not tested.

${ }^{*} P<.05,{ }^{* *} P<.01 P$ for trend with time.

and once against SM), were detected in the course of the observation period in a total of eight patients. In most of them, their appearance was transitory. In two patients (nos. 1 and 6, both of them were females), autoantibodies were detected against three antigens: in two patients (nos. 4 and 7) against two antigens and in four patients (nos. 2, 3, 9 and 10) against one antigen only. The most frequently detected autoantibodies were reactive with TPO, TG and nucleus (in all instances in three patients). In two patients antibodies reactive with SM were detected. In 1 of these (patient no. 1), they were present in the pretreatment serum sample, disappeared after starting the therapy with $\mathrm{HU}$ and were not detected later on when $\mathrm{HU}$ was gradually replaced by IFN $\alpha$ and IM. A similar phenomenon was seen in patient no. 7 , in whom the initial reactivity with TPO and TG disappeared in the course of the therapy. Thus no consistent pattern was evident and, because of the multiplicity of drugs employed for individual patients, no clear dependence on the therapy used was observed. It may be of interest that the antibodies against mitochondria (AMAb) and endomysium (E-AAb and E-GAb) were never detected.

There seems to be some, but not quite a consistent correlation with the mode of therapy and the development of autoantibodies. Autoantibodies were detected in five of six patients treated with IFN $\alpha$ and in four out of five patients treated with $\mathrm{HU}$ (all of them had later on been treated with $\operatorname{IFN} \alpha$ ) but in only two out of four patients exclusively treated by TKI (either IM or DS). Furthermore, in four patients autoantibodies detected after $\mathrm{HU}$ and IFN $\alpha$ treatment disappeared when these drugs were replaced by IM.

3.3. Complement $C 3$ and C4 Components. In the pretreatment sera normal levels of $\mathrm{C} 3$ were observed in all but one patient (no. 11), in whom the level was below the norm. As indicated in Table 4, little variation of C3 levels was observed in the course of the observation period; still, in three patient's a transitory decrease of its level below the standard laboratory range was observed. In all instances (including patient no. 11), their levels returned to the norm by the time hematological remission was achieved. In two of three patients with the increased levels of $\mathrm{C} 4$ in pre-treatment sera (nos. 4, and 5), their levels dropped in the course of treatment.

3.4. C-Reactive Protein and IL-6. The results are also presented in Table 4. Prior to the start of the therapy, increased levels of CRP were detected in six patients. Judging by the levels detected in the last samples collected, the levels dropped to the norm in all of them. However, it is noteworthy that in two patients (nos. 3 and 8), in spite of the hematological remission having been achieved, their levels increased, and in four other patients (nos. 1, 2, 5 and 7) a transitory increase of CRP was detected in the course of the observation period. In patient no. 7 the increased level of CRP corresponded with an acute infection of the upper respiratory tract. In the other four patients (nos. 1, 3, 5 and 7) no clinical complications at the time of CRP increase were observed or reported by the patients. As concerns IL-6 levels, there was a nearly general decrease in association with the hematological remission. The decrease for the whole group was highly significant $(P=.001)$. Again, as in the previous study [22], no clear correlation between IL-6 and CRP levels was apparent.

3.5. Lymphocyte Subpopulations. As indicated in Table 5, in spite of the drop of lymphocytes (shown in Table 1), there was little variation in the percentage of CD3+ cells in the course of the observation period, including patient no. 6, in whom lymphopenia was detected in the pretreatment sample (see Table 1), and patient no. 10 with $\mathrm{CD} 3+$ lymphocyte percentage slightly below the norm. The only exception was patient no. 11, initially treated with $\mathrm{HU}$ who after a rather long interval without any treatment was treated with DS. In this patient a marked drop of CD3+ cells was detected. It is clear, however, that this decrease was relative, reflecting a substantial increase of NK cells. The changes in the percentages of CD4+ and CD8+ were slight or moderate in nearly all patients and no consistent pattern 
TABle 3: Autoantibodies.

\begin{tabular}{|c|c|c|c|c|c|c|c|c|c|c|}
\hline No. & Therapy & TPOAb & TGAb & ANAb & ANCAb & AMAb & ENDOAb A & ENDOAb G & SMAb & DESMAb \\
\hline \multirow{7}{*}{ (1) } & $\mathrm{dg}, \mathrm{HU}$ & $\mathrm{n}^{\mathrm{a}}$ & $\mathrm{n}$ & $\mathrm{n}$ & $\mathrm{n}$ & $\mathrm{n}$ & $\mathrm{n}$ & $\mathrm{n}$ & $\mathbf{p}^{\mathrm{b}}$ & $\mathrm{n}$ \\
\hline & IFN & $\mathrm{n}$ & $\mathrm{n}$ & $\mathrm{n}$ & $\mathbf{p}$ & $\mathrm{n}$ & $\mathrm{n}$ & $\mathrm{n}$ & $\mathrm{n}$ & $\mathrm{n}$ \\
\hline & IFN & $\mathrm{n}$ & $\mathrm{n}$ & $\mathrm{n}$ & $\mathrm{n}$ & $\mathrm{n}$ & $\mathrm{n}$ & $\mathrm{n}$ & $\mathrm{n}$ & p \\
\hline & IM & $\mathrm{n}$ & $\mathrm{n}$ & $\mathrm{n}$ & p & $\mathrm{n}$ & $\mathrm{n}$ & $\mathrm{n}$ & $\mathrm{n}$ & p \\
\hline & IM & $\mathrm{n}$ & $\mathrm{n}$ & $\mathrm{n}$ & p & $\mathrm{n}$ & $\mathrm{n}$ & $\mathrm{n}$ & $\mathrm{n}$ & p \\
\hline & IM & $\mathrm{n}$ & $\mathrm{n}$ & $\mathrm{n}$ & $\mathrm{n}$ & $\mathrm{n}$ & $\mathrm{n}$ & $\mathrm{n}$ & $\mathrm{n}$ & p \\
\hline & DS & $\mathrm{n}$ & $\mathrm{n}$ & $\mathrm{n}$ & $\mathrm{n}$ & $\mathrm{n}$ & $\mathrm{n}$ & $\mathrm{n}$ & $\mathrm{n}$ & p \\
\hline \multirow{7}{*}{ (2) } & $\mathrm{dg}, \mathrm{HU}$ & $\mathrm{n}$ & $\mathrm{n}$ & $\mathrm{n}$ & $\mathrm{n}$ & $\mathrm{n}$ & $\mathrm{n}$ & $\mathrm{n}$ & $\mathrm{n}$ & $\mathrm{n}$ \\
\hline & IFN & $\mathrm{n}$ & $\mathrm{n}$ & $\mathrm{n}$ & $\mathrm{n}$ & $\mathrm{n}$ & $\mathrm{n}$ & $\mathrm{n}$ & $\mathrm{n}$ & $\mathrm{n}$ \\
\hline & IFN & $\mathrm{n}$ & $\mathrm{n}$ & $\mathrm{n}$ & $\mathrm{n}$ & $\mathrm{n}$ & $\mathrm{n}$ & $\mathrm{n}$ & $\mathrm{n}$ & $\mathrm{n}$ \\
\hline & IFN & $\mathrm{n}$ & $\mathrm{n}$ & p & $\mathrm{n}$ & $\mathrm{n}$ & $\mathrm{n}$ & $\mathrm{n}$ & $\mathrm{n}$ & $\mathrm{n}$ \\
\hline & IM & $\mathrm{n}$ & $\mathrm{n}$ & $\mathrm{n}$ & $\mathrm{n}$ & $\mathrm{n}$ & $\mathrm{n}$ & $\mathrm{n}$ & $\mathrm{n}$ & $\mathrm{n}$ \\
\hline & IM & $\mathrm{n}$ & $\mathrm{n}$ & $\mathrm{n}$ & $\mathrm{n}$ & $\mathrm{n}$ & $\mathrm{n}$ & $\mathrm{n}$ & $\mathrm{n}$ & $\mathrm{n}$ \\
\hline & $\mathrm{IM}$ & $\mathrm{n}$ & $\mathrm{n}$ & $\mathrm{n}$ & $\mathrm{n}$ & $\mathrm{n}$ & $\mathrm{n}$ & $\mathrm{n}$ & $\mathrm{n}$ & $\mathrm{n}$ \\
\hline \multirow{6}{*}{ (3) } & dg, HU & $\mathrm{n}$ & $\mathrm{n}$ & $\mathrm{n}$ & $\mathrm{n}$ & $\mathrm{n}$ & $\mathrm{n}$ & $\mathrm{n}$ & $\mathrm{n}$ & $\mathrm{n}$ \\
\hline & IFN & $\mathrm{n}$ & $\mathrm{n}$ & $\mathrm{n}$ & $\mathrm{n}$ & $\mathrm{n}$ & $\mathrm{n}$ & $\mathrm{n}$ & $\mathrm{n}$ & $\mathrm{n}$ \\
\hline & IFN & $\mathrm{n}$ & $\mathrm{n}$ & $\mathrm{n}$ & $\mathrm{n}$ & $\mathrm{n}$ & $\mathrm{n}$ & $\mathrm{n}$ & $\mathbf{p}$ & $\mathrm{n}$ \\
\hline & IM & $\mathrm{n}$ & $\mathrm{n}$ & $\mathrm{n}$ & $\mathrm{n}$ & $\mathrm{n}$ & $\mathrm{n}$ & $\mathrm{n}$ & $\mathrm{n}$ & $\mathrm{n}$ \\
\hline & IM & $\mathrm{n}$ & $\mathrm{n}$ & $\mathrm{n}$ & $\mathrm{n}$ & $\mathrm{n}$ & $\mathrm{n}$ & $\mathrm{n}$ & $\mathrm{p}$ & $\mathrm{n}$ \\
\hline & IM & $\mathrm{n}$ & $\mathrm{n}$ & $\mathrm{n}$ & $\mathrm{n}$ & $\mathrm{n}$ & $\mathrm{n}$ & $\mathrm{n}$ & $\mathrm{n}$ & $\mathrm{n}$ \\
\hline \multirow{5}{*}{ (4) } & $\mathrm{dg}, \mathrm{HU}$ & $\mathrm{n}$ & $\mathrm{n}$ & $\mathrm{n}$ & $\mathrm{n}$ & $\mathrm{n}$ & $\mathrm{n}$ & $\mathrm{n}$ & $\mathrm{n}$ & $\mathrm{n}$ \\
\hline & IFN & $\mathrm{n}$ & $\mathrm{n}$ & $\mathrm{n}$ & $\mathrm{n}$ & $\mathrm{n}$ & $\mathrm{n}$ & $\mathrm{n}$ & $\mathrm{n}$ & $\mathrm{n}$ \\
\hline & IFN & $\mathrm{n}$ & $\mathrm{n}$ & $\mathrm{n}$ & $\mathrm{n}$ & $\mathrm{n}$ & $\mathrm{n}$ & $\mathrm{n}$ & $\mathrm{n}$ & p \\
\hline & IM & p & $\mathrm{n}$ & $\mathrm{n}$ & $\mathrm{n}$ & $\mathrm{n}$ & $\mathrm{n}$ & $\mathrm{n}$ & $\mathrm{n}$ & $\mathrm{n}$ \\
\hline & IM & $\mathrm{n}$ & $\mathrm{n}$ & $\mathrm{n}$ & $\mathrm{n}$ & $\mathrm{n}$ & $\mathrm{n}$ & $\mathrm{n}$ & $\mathrm{n}$ & $\mathrm{n}$ \\
\hline \multirow{6}{*}{ (5) } & dg, HU & $\mathrm{n}$ & $\mathrm{n}$ & $\mathrm{n}$ & $\mathrm{n}$ & $\mathrm{n}$ & $\mathrm{n}$ & $\mathrm{n}$ & $\mathrm{n}$ & $\mathrm{n}$ \\
\hline & $\mathrm{HU}$ & $\mathrm{n}$ & $\mathrm{n}$ & $\mathrm{n}$ & $\mathrm{n}$ & $\mathrm{n}$ & $\mathrm{n}$ & $\mathrm{n}$ & $\mathrm{n}$ & $\mathrm{n}$ \\
\hline & IFN & $\mathrm{n}$ & $\mathrm{n}$ & $\mathrm{n}$ & $\mathrm{n}$ & $\mathrm{n}$ & $\mathrm{n}$ & $\mathrm{n}$ & $\mathrm{n}$ & $\mathrm{n}$ \\
\hline & IM & $\mathrm{n}$ & $\mathrm{n}$ & $\mathrm{n}$ & $\mathrm{n}$ & $\mathrm{n}$ & $\mathrm{n}$ & $\mathrm{n}$ & $\mathrm{n}$ & $\mathrm{n}$ \\
\hline & IM & $\mathrm{n}$ & $\mathrm{n}$ & $\mathrm{n}$ & $\mathrm{n}$ & $\mathrm{n}$ & $\mathrm{n}$ & $\mathrm{n}$ & $\mathrm{n}$ & $\mathrm{n}$ \\
\hline & IM & $\mathrm{n}$ & $\mathrm{n}$ & $\mathrm{n}$ & $\mathrm{n}$ & $\mathrm{n}$ & $\mathrm{n}$ & $\mathrm{n}$ & $\mathrm{n}$ & $\mathrm{n}$ \\
\hline \multirow{5}{*}{ (6) } & $\mathrm{dg}$, IFN & $\mathrm{p}$ & $\mathrm{n}$ & $\mathrm{n}$ & $\mathrm{n}$ & $\mathrm{n}$ & $\mathrm{n}$ & $\mathrm{n}$ & $\mathrm{n}$ & $\mathrm{n}$ \\
\hline & IFN & $\mathbf{p}$ & $\mathrm{p}$ & $\mathrm{n}$ & $\mathrm{n}$ & $\mathrm{n}$ & $\mathrm{n}$ & $\mathrm{n}$ & $\mathrm{n}$ & $\mathrm{n}$ \\
\hline & IM & $\mathbf{p}$ & $\mathrm{n}$ & $\mathbf{p}$ & $\mathrm{n}$ & $\mathrm{n}$ & $\mathrm{n}$ & $\mathrm{n}$ & $\mathrm{n}$ & $\mathrm{n}$ \\
\hline & DS & $\mathbf{p}$ & $\mathrm{n}$ & $\mathrm{n}$ & $\mathrm{n}$ & $\mathrm{n}$ & $\mathrm{n}$ & $\mathrm{n}$ & $\mathrm{n}$ & $\mathrm{n}$ \\
\hline & DS & $\mathbf{p}$ & $\mathrm{n}$ & $\mathrm{n}$ & $\mathrm{n}$ & $\mathrm{n}$ & $\mathrm{n}$ & $\mathrm{n}$ & $\mathrm{n}$ & $\mathrm{n}$ \\
\hline \multirow{5}{*}{ (7) } & $\mathrm{dg}, \mathrm{HU}$ & $\mathrm{p}$ & $\mathrm{p}$ & $\mathrm{n}$ & $\mathrm{n}$ & $\mathrm{n}$ & $\mathrm{n}$ & $\mathrm{n}$ & $\mathrm{n}$ & $\mathrm{n}$ \\
\hline & $\mathrm{HU}$ & $\mathbf{p}$ & p & $\mathrm{n}$ & $\mathrm{n}$ & $\mathrm{n}$ & $\mathrm{n}$ & $\mathrm{n}$ & $\mathrm{n}$ & $\mathrm{n}$ \\
\hline & $\mathrm{HU}$ & n.t. ${ }^{c}$ & n.t. & $\mathrm{n}$ & $\mathrm{n}$ & $\mathrm{n}$ & $\mathrm{n}$ & $\mathrm{n}$ & $\mathrm{n}$ & $\mathrm{n}$ \\
\hline & IM & $\mathbf{p}$ & $\mathbf{n}$ & $\mathrm{n}$ & $\mathrm{n}$ & $\mathrm{n}$ & $\mathrm{n}$ & $\mathrm{n}$ & $\mathrm{n}$ & $\mathrm{n}$ \\
\hline & IM & $\mathrm{n}$ & $\mathrm{n}$ & $\mathrm{n}$ & $\mathrm{n}$ & $\mathrm{n}$ & $\mathrm{n}$ & $\mathrm{n}$ & $\mathrm{n}$ & $\mathrm{n}$ \\
\hline \multirow{6}{*}{ (8) } & $\mathrm{dg}, \mathrm{IM}$ & $\mathrm{n}$ & $\mathrm{n}$ & $\mathrm{n}$ & $\mathrm{n}$ & $\mathrm{n}$ & $\mathrm{n}$ & $\mathrm{n}$ & $\mathrm{n}$ & $\mathrm{n}$ \\
\hline & IM & $\mathrm{n}$ & $\mathrm{n}$ & $\mathrm{n}$ & $\mathrm{n}$ & $\mathrm{n}$ & $\mathrm{n}$ & $\mathrm{n}$ & $\mathrm{n}$ & $\mathrm{n}$ \\
\hline & IM & $\mathrm{n}$ & $\mathrm{n}$ & $\mathrm{n}$ & $\mathrm{n}$ & $\mathrm{n}$ & $\mathrm{n}$ & $\mathrm{n}$ & $\mathrm{n}$ & $\mathrm{n}$ \\
\hline & IM & $\mathrm{n}$ & $\mathrm{n}$ & $\mathrm{n}$ & $\mathrm{n}$ & $\mathrm{n}$ & $\mathrm{n}$ & $\mathrm{n}$ & $\mathrm{n}$ & $\mathrm{n}$ \\
\hline & IM & n.t. & n.t. & $\mathrm{n}$ & $\mathrm{n}$ & $\mathrm{n}$ & $\mathrm{n}$ & $\mathrm{n}$ & $\mathrm{n}$ & $\mathrm{n}$ \\
\hline & IM & $\mathrm{n}$ & $\mathrm{n}$ & $\mathrm{n}$ & $\mathrm{n}$ & $\mathrm{n}$ & $\mathrm{n}$ & $\mathrm{n}$ & $\mathrm{n}$ & $\mathrm{n}$ \\
\hline
\end{tabular}


TABle 3: Continued.

\begin{tabular}{|c|c|c|c|c|c|c|c|c|c|c|}
\hline No. & Therapy & TPOAb & TGAb & ANAb & ANCAb & AMAb & ENDOAb A & ENDOAb G & SMAb & DESMAb \\
\hline \multirow{3}{*}{ (9) } & dg, IM & $\mathrm{n}$ & $\mathrm{n}$ & $\mathrm{n}$ & $\mathrm{n}$ & $\mathrm{n}$ & $\mathrm{n}$ & $\mathrm{n}$ & $\mathrm{n}$ & $\mathrm{n}$ \\
\hline & IM & $\mathrm{n}$ & $\mathrm{n}$ & $\mathrm{n}$ & $\mathrm{n}$ & $\mathrm{n}$ & $\mathrm{n}$ & $\mathrm{n}$ & $\mathrm{n}$ & $\mathrm{n}$ \\
\hline & IM & $\mathrm{n}$ & $\mathrm{n}$ & $\mathrm{n}$ & p & $\mathrm{n}$ & $\mathrm{n}$ & $\mathrm{n}$ & $\mathrm{n}$ & $\mathrm{n}$ \\
\hline \multirow{4}{*}{ (10) } & $\mathrm{dg}, \mathrm{IM}$ & $\mathrm{n}$ & $\mathrm{n}$ & $\mathrm{n}$ & $\mathrm{n}$ & $\mathrm{n}$ & $\mathrm{n}$ & $\mathrm{n}$ & $\mathrm{n}$ & $\mathrm{n}$ \\
\hline & IM & $\mathrm{n}$ & $\mathrm{n}$ & $\mathrm{n}$ & $\mathrm{n}$ & $\mathrm{n}$ & $\mathrm{n}$ & $\mathrm{n}$ & $\mathrm{n}$ & $\mathrm{n}$ \\
\hline & IM & $\mathrm{n}$ & $\mathrm{n}$ & $\mathrm{n}$ & $\mathrm{n}$ & $\mathrm{n}$ & $\mathrm{n}$ & $\mathrm{n}$ & $\mathrm{n}$ & $\mathrm{n}$ \\
\hline & IM & $\mathrm{n}$ & $\mathrm{n}$ & $\mathbf{p}$ & $\mathrm{n}$ & $\mathrm{n}$ & $\mathrm{n}$ & $\mathrm{n}$ & $\mathrm{n}$ & $\mathrm{n}$ \\
\hline \multirow{3}{*}{ (11) } & dg, HU & $\mathrm{n}$ & $\mathrm{n}$ & $\mathrm{n}$ & $\mathrm{n}$ & $\mathrm{n}$ & $\mathrm{n}$ & $\mathrm{n}$ & $\mathrm{n}$ & $\mathrm{n}$ \\
\hline & DS & $\mathrm{n}$ & $\mathrm{n}$ & $\mathrm{n}$ & $\mathrm{n}$ & $\mathrm{n}$ & $\mathrm{n}$ & $\mathrm{n}$ & $\mathrm{n}$ & $\mathrm{n}$ \\
\hline & DS & $\mathrm{n}$ & $\mathrm{n}$ & $\mathrm{n}$ & $\mathrm{n}$ & $\mathrm{n}$ & $\mathrm{n}$ & $\mathrm{n}$ & $\mathrm{n}$ & $\mathrm{n}$ \\
\hline
\end{tabular}

TPOAb: antibodies against thyroidal peroxidase; TGAb: antibodies against thyreoglobulin; ANAb: antinuclear antibodies; ANCAb: antibodies against the cytoplasm of neutrophils; AMAb: antimitochondrial antibodies; ENDOAb A, ENDOAb G: antibodies of the IgA and IgG classes against endomysium; SMAB: antibodies against smooth muscless; DESMAb: antidesmosomal antibodies.

${ }^{a}$ Negative for the respective antibodies.

${ }^{b}$ Positive for the respective antibody.

${ }^{c}$ n.t.:not tested.

was evident. Still, in four of seven patients, in whose pretreatment samples the percentage of CD8 cells was below the norm, their percentages did not reach the lower limit of the referential range. In four patients (nos. 4, 5, 6 and 10) the remission was associated with an increase in CD19+ cells. When the distribution of lymphocyte subpopulations in the first and last sample was compared, significant differences $(P<.05$ to $<.001)$ were encountered in six patients (nos. 1,3 , $5,6,9$ and 11). However, no consistent pattern was apparent and thus the real significance of these findings is doubtful.

3.6. Intracellular Production of Cytokines. The results are presented in Table 6. Two observations may be of interest. Possibly the most important one was an increase of the CD3+ cells, which produce the cytokines, in most of the patients, including those, in whom the production of these cytokines prior to the start of the therapy had been pathologically low (e.g., in the case of IL-2, patients nos. 3 and 8). Of the ten patients, which could be evaluated, the percentage of IL-2producing cells increased in seven, IL-4-producing cells also in seven, TNF $\alpha$-producing cells in six and INF $\gamma$ producing cells in seven. In some of the patients the level of cytokine production remained essentially unchanged (e.g., patient no. 8 , all four cytokines) and in one patient there was a drop of IL-2 and IL-4 production (patient no. 1) and in another patient the drop of INF $\gamma$ production (patient no. 2).

The other noteworthy observation, closely associated with the first one, was an increase in cells producing more than one cytokine after stimulation, as reflected by an increase of the percentage sum of reactive cells. The increase was expressed in terms of the Cytokine Production Index (CPI) given by the ratio between the sum of cytokineproducing cells as detected in the last sample and the sum of cytokine producing cells in the first sample available (i.e., in all but one patient before the start of therapy). A marked increase in CPI was detected in seven (nos. 3, 4, 5, 6, 7, 9 and 10) out of 10 patients which could be evaluated. The difference for the group was highly significant $(P=.006)$.

\subsection{Antibodies Against Herpesviruses and Papillomaviruses.} To clarify whether treatment of the CML patients with HU, IFN $\alpha$ or TKI was associated with activation of latent and/or persistent virus infections, we tested sera from the patients for presence of antibodies against four human herpesviruses and six human papillomaviruses. The results are summarized in Tables 7 and 8. For the sake of simplicity, only the results of testing sera taken prior to the start of any treatment and at the end of the observation period are presented. It is evident that there was only very little difference between the two sets of sera. In one patient (no. 11) treated with DS, cytomegalovirus infection was reactivated as revealed by a very marked increase in $\operatorname{IgG}$ antibody and the appearance of IgM antibody (results not shown).

\section{Discussion}

In the preceding paper [22], we showed that CML patients before treatment differed from matched healthy subjects in a number of immunological parameters. The major aim of the present investigation was to find out, whether these aberrations persisted, decreased, or disappeared in the course of treatment, in particular whether these changes correlated with the induction of hematological and/or cytogenetic remission, whether and how they were influenced by the drugs used for treatment, and, in the long run, what was their prognostic value, if any. Our efforts were seriously hampered by two circumstances, that is, by the loss of 13 out of 24 patients originally enrolled and, for ethical reasons, by the impossibility to maintain the original treatment regimen 
TABle 4: Complement components, CRP and IL-6.

\begin{tabular}{|c|c|c|c|c|c|}
\hline No. & Therapy & C3 & C4 & CRP & IL-6 \\
\hline \multirow{7}{*}{ (1) } & $\mathrm{dg}, \mathrm{HU}$ & 0.94 & 0.40 & 5.2 & 5.10 \\
\hline & IFN & 0.67 & 0.37 & 3.0 & 2.53 \\
\hline & IFN & 0.83 & 0.42 & 24.4 & 5.42 \\
\hline & IM & 0.71 & 0.30 & 3.5 & 1.83 \\
\hline & IM & 0.53 & 0.21 & 3.5 & 1.53 \\
\hline & IM & 0.72 & 0.30 & 3.3 & 1.67 \\
\hline & DS & 1.26 & 0.52 & 3.2 & 2.72 \\
\hline \multirow{7}{*}{ (2) } & $\mathrm{dg}, \mathrm{HU}$ & 1.24 & 0.30 & 12.8 & 9.54 \\
\hline & IFN & 1.22 & 0.28 & 3.0 & 3.47 \\
\hline & IFN & 1.22 & 0.28 & 3.5 & 3.87 \\
\hline & IFN & 1.15 & 0.25 & 3.5 & 4.92 \\
\hline & IM & 1.19 & 0.26 & 3.2 & 3.21 \\
\hline & IM & 1.27 & 0.27 & 5.4 & 2.45 \\
\hline & IM & 1.20 & $0.24^{*}$ & 3.2 & $2.82 *$ \\
\hline \multirow{6}{*}{ (3) } & $\mathrm{dg}, \mathrm{HU}$ & 1.19 & 0.26 & 3.0 & 3.9 \\
\hline & IFN & 1.14 & 0.26 & 3.0 & 1.8 \\
\hline & IFN & 0.94 & 0.24 & 3.5 & 1.5 \\
\hline & IM & 1.15 & 0.27 & 3.3 & 2.16 \\
\hline & IM & 1.20 & 0.26 & 3.2 & 1.14 \\
\hline & IM & 1.40 & 0.30 & 32.9 & 3.03 \\
\hline \multirow{5}{*}{ (4) } & $\mathrm{dg}, \mathrm{HU}$ & 1.35 & 0.38 & 11.6 & 4.40 \\
\hline & IFN & 0.90 & 0.21 & 3.0 & 1.54 \\
\hline & IFN & 1.11 & 0.23 & 3.5 & 1.97 \\
\hline & IM & 1.20 & 0.27 & 3.2 & 1.45 \\
\hline & IM & 1.06 & 0.25 & 3.2 & 1.50 \\
\hline \multirow{6}{*}{ (5) } & $\mathrm{dg}, \mathrm{HU}$ & 1.03 & 1.23 & 3.0 & 3.30 \\
\hline & $\mathrm{HU}$ & 0.97 & 0.21 & 3.5 & 3.67 \\
\hline & IFN & 0.80 & 0.20 & 3.5 & 2.16 \\
\hline & IM & 0.91 & 0.19 & 3.2 & 2.49 \\
\hline & IM & 1.14 & 0.23 & 8.8 & 2.30 \\
\hline & IM & 1.00 & 0.25 & 3.4 & 1.99 \\
\hline \multirow{5}{*}{ (6) } & $\mathrm{dg}$, IFN & 0.98 & 0.21 & 3.0 & 2.80 \\
\hline & IFN & 0.69 & 0.19 & n.t. ${ }^{\mathrm{a}}$ & 1.82 \\
\hline & IM & 0.78 & 0.17 & 3.5 & 1.87 \\
\hline & DS & 1.31 & 0.30 & 3.2 & 2.31 \\
\hline & DS & 1.14 & 0.24 & 3.2 & 0.00 \\
\hline \multirow{5}{*}{ (7) } & $\mathrm{dg}, \mathrm{HU}$ & 0.91 & 0.16 & 3.5 & 5.08 \\
\hline & $\mathrm{HU}$ & 0.68 & 0.15 & 3.5 & 4.24 \\
\hline & $\mathrm{HU}$ & 0.91 & 0.18 & 3.3 & 5.29 \\
\hline & IM & 0.91 & 0.19 & 21.3 & 1.82 \\
\hline & IM & 0.98 & 0.17 & 3.2 & 3.00 \\
\hline \multirow{6}{*}{ (8) } & dg, IM & 0.93 & 0.19 & 3.5 & 3.80 \\
\hline & IM & 0.94 & 0.19 & 3.8 & 2.63 \\
\hline & IM & 0.89 & 0.17 & 3.2 & 2.31 \\
\hline & IM & 0.89 & 0.18 & 3.3 & 1.53 \\
\hline & IM & 1.07 & 0.26 & 9.4 & 0.27 \\
\hline & IM & 1.11 & 0.33 & 6.1 & $1.70^{*}$ \\
\hline
\end{tabular}


TABle 4: Continued.

\begin{tabular}{cccccc}
\hline No. & Therapy & C3 & C4 & CRP & IL-6 \\
\hline \multirow{4}{*}{$9)^{4}$} & dg, IM & 0.86 & 0.29 & 23.0 & 14.20 \\
& IM & 0.91 & 0.24 & 3.2 & 1.21 \\
\hline \multirow{4}{*}{$(10)$} & $1.05^{* *}$ & 0.27 & 3.2 & $1.00^{*}$ \\
& IM & 0.79 & 0.30 & 5.9 & 16.71 \\
& dg, IM & 0.86 & 0.24 & 3.3 & 4.97 \\
& IM & 0.81 & 0.17 & 3.2 & n.t. \\
& IM & 0.76 & 0.17 & 3.2 & 5.20 \\
$(11)$ & IM & 0.65 & 0.36 & 6.8 & 2.23 \\
& dg, HU & 0.59 & 0.25 & 3.2 & 3.50 \\
\hline
\end{tabular}

a.t.:not tested.

${ }^{*} P<.05,{ }^{* *} P<.01 P$ for trend with time.

with either HU or INF $\alpha$. Because of the changes in the treatment modalities, the original set of patients split into two groups. The first one consisted of eight patients originally treated with $\mathrm{HU}$ and/or INF $\alpha$ and subsequently with TKI, while the remaining three patients treated exclusively with TKI constituted the second group.

Of these two shortcomings, the diminution of our set of patients from 24 to 11 was certainly the more important one. This reduction increased the difficulties already inherent in the group studied, that is, its inhomogeneity (age, sex, different treatments), as regards evaluation of the data obtained. Still, because in all patients hematological remission and in nearly all of them even CCR was achieved, this bringing an element of homogeneity into the study group, some conclusions can be drawn. The most important one is the nearly general association of the remission with a normalization of the aberrant immunity parameters, both humoral a cellular. One can assume that this normalization was due to an alleviation of the CML-associated processes. The continuing followup of the patients should reveal whether any relapse of the disease would be associated with deviations from the norm and with the reappearance of the same or appearance of some other aberrations.

As regards the levels of immunoglobulins, there was a tendency towards their decrease, predominantly IgM. The gradual decrease of IgM levels was highly significant. These findings correspond with the results reported by Steegmann et al. [24], who described considerable reduction of levels of serum immunoglobulins, including IgM, in patients previously exposed to IFN $\alpha$ and then treated with IM; according to their findings, the reduction of immunoglobulins was especially marked in patients expressing a pronounced cytogenetic response. A marked selective effect of IM treatment on serum IgM level in one patient has been reported by Nagasawa and Mizutan [25]. We are unable to provide any reasonable explanation for our observation. We can only speculate that the decrease observed was due to qualitative alteration of B cells by the therapy employed. Otherwise, no consistent pattern was apparent. We only rarely detected decrease in IgA levels, which we found significantly increased in the pretreatment CML patients when compared with their matched healthy controls [22].

When monitoring the presence of autoantibodies, we detected them in five out of six patients treated with INF $\alpha$. These antibodies were directed against cytoplasm of neutrophils (ANCAb), smooth muscles (ASMAb), nucleus (ANAb), thyreoglobulin (ATG), or thyroidal peroxidase (ATPO). This is not particularly surprising, since INF $\alpha$ exhibits allo- and autostimulation activity on antigen presenting cells. However, its activity in vivo may depend on the simultaneous regulation of network of immune cells rather than on the activation of individual populations [10]. INF $\alpha$, but not IM, was reported to cause an increased transcription of proteinase 3 in CD14-positive monocytes, this suggesting another possible mechanism, by which IFN $\alpha$ may promote self-antigen presentation [7]. In our study the appearance of autoantibodies was in most instances of transitory character and that their disappearance quite frequently followed the replacement of INF $\alpha$ by IM. However, autoantibodies also developed in two out of five patients untreated with INF $\alpha$. It is therefore difficult to claim, on the basis of the present results, that INF $\alpha$ was markedly more active than TKI in inducing autoantibodies. It should be added that, in our patients, the development of antibodies did not manifest itself in any clinically recognizable disease, with the possible exception of the simultaneous presence of ANCAb and vasculitis in patient no. 1. This possible association and the subsequent cure of the vasculitis in parallel with the disappearance of the antibody after IM treatment seems to be in line with a recent report [26].

As concerns the $\mathrm{C} 3$ and $\mathrm{C} 4$ components of complement there was little variation during the observation period. Again, there was a tendency to normalization. This seems to be in agreement with other findings in patients with hematological malignancies including CML [27]; however, the changes we observed were rather small and their significance is questionable. It seems clear that the follow-up of 
TABLE 5: Lymphocytes subpopulations.

\begin{tabular}{|c|c|c|c|c|c|c|}
\hline No. & Therapy & $\mathrm{CD}^{\mathrm{a}}$ & $\mathrm{CD} 4$ & $\mathrm{CD} 8$ & CD19 & CD3-CD16,56+ \\
\hline \multirow{7}{*}{ (1) } & dg, HU & 72 & 54 & 18 & 14 & 14 \\
\hline & IFN & 74 & 53 & 21 & 4 & 13 \\
\hline & IFN & 84 & 52 & 32 & 10 & 6 \\
\hline & $\mathrm{IM}$ & 76 & 48 & 28 & 11 & 12 \\
\hline & IM & 76 & 49 & 24 & 10 & 12 \\
\hline & $\mathrm{IM}$ & 73 & 47 & 26 & 13 & 10 \\
\hline & DS & 79 & 51 & 27 & 5 & 14 \\
\hline \multirow{7}{*}{ (2) } & $\mathrm{dg}, \mathrm{HU}$ & 86 & 61 & 25 & 5 & 7 \\
\hline & IFN & 84 & 52 & 32 & 3 & 13 \\
\hline & IFN & 75 & 50 & 25 & 4 & 21 \\
\hline & IFN & 82 & 70 & 12 & 8 & 9 \\
\hline & IM & 69 & 54 & 15 & 11 & 20 \\
\hline & IM & 78 & 61 & 15 & 7 & 14 \\
\hline & $\mathrm{IM}$ & 80 & 62 & 15 & 7 & 13 \\
\hline \multirow{6}{*}{ (3) } & $\mathrm{dg}, \mathrm{HU}$ & 76 & 39 & 37 & 12 & 12 \\
\hline & IFN & 79 & 42 & 36 & 8 & 13 \\
\hline & IFN & 73 & 44 & 29 & 13 & 13 \\
\hline & $\mathrm{IM}$ & 69 & 42 & 27 & 17 & 13 \\
\hline & $\mathrm{IM}$ & 72 & 48 & 24 & 15 & 13 \\
\hline & IM & 63 & 44 & 19 & 12 & 25 \\
\hline \multirow{5}{*}{ (4) } & $\mathrm{dg}, \mathrm{HU}$ & 74 & 60 & 14 & 6 & 19 \\
\hline & IFN & 86 & 59 & 27 & 6 & 8 \\
\hline & IFN & 68 & 39 & 28 & 10 & 21 \\
\hline & IM & 75 & 52 & 23 & 13 & 12 \\
\hline & IM & 78 & 53 & 25 & 12 & 10 \\
\hline \multirow{6}{*}{ (5) } & $\mathrm{dg}, \mathrm{HU}$ & 62 & 42 & 18 & 6 & 32 \\
\hline & $\mathrm{HU}$ & 66 & 43 & 23 & 20 & 14 \\
\hline & IFN & 62 & 40 & 22 & 24 & 14 \\
\hline & IM & 65 & 42 & 23 & 15 & 20 \\
\hline & IM & 66 & 41 & 20 & 13 & 20 \\
\hline & IM & 67 & 43 & 24 & 15 & 17 \\
\hline \multirow{5}{*}{ (6) } & dg, IFN & 83 & 40 & 43 & 10 & 6 \\
\hline & IFN & 77 & 53 & 23 & 11 & 11 \\
\hline & IM & 76 & 52 & 23 & 11 & 12 \\
\hline & DS & 76 & 31 & 43 & 11 & 12 \\
\hline & DS & 65 & 29 & 34 & 23 & 12 \\
\hline \multirow{5}{*}{ (7) } & $\mathrm{dg}, \mathrm{HU}$ & 75 & 51 & 24 & 10 & 15 \\
\hline & $\mathrm{HU}$ & 81 & 54 & 27 & 7 & 12 \\
\hline & $\mathrm{HU}$ & 74 & 48 & 21 & 11 & 14 \\
\hline & IM & 73 & 52 & 20 & 12 & 14 \\
\hline & IM & 73 & 53 & 19 & 10 & 16 \\
\hline \multirow{6}{*}{ (8) } & $\mathrm{dg}, \mathrm{IM}$ & 76 & 54 & 22 & 9 & 14 \\
\hline & IM & 72 & 55 & 17 & 13 & 16 \\
\hline & IM & 76 & 54 & 22 & 8 & 15 \\
\hline & IM & 77 & 55 & 19 & 10 & 11 \\
\hline & IM & 74 & 54 & 17 & 9 & 17 \\
\hline & IM & 74 & 57 & 17 & 12 & 14 \\
\hline
\end{tabular}


TABle 5: Continued.

\begin{tabular}{ccccccc}
\hline No. & Therapy & CD3 $^{\text {a }}$ & CD4 & CD8 & CD19 & CD3-CD16,56+ \\
\hline \multirow{4}{*}{$(9)$} & dg, IM & 85 & 29 & 53 & 3 & 12 \\
& IM & 76 & 34 & 38 & 7 & 15 \\
& IM & 74 & 37 & 34 & 9 & 15 \\
\hline \multirow{4}{*}{$(10)$} & dg, IM & 67 & 52 & 14 & 14 & 16 \\
& IM & 61 & 40 & 21 & 20 & 18 \\
& IM & 55 & 37 & 16 & 18 & 25 \\
\hline \multirow{3}{*}{$(11)$} & IM & 54 & 37 & 14 & 23 & 23 \\
& dg,HU & 67 & 57 & 9 & 20 & 23 \\
& DS & 59 & 49 & 9 & 16 & 50 \\
\hline
\end{tabular}

${ }^{\mathrm{a}}$ The figures indicate the percentages of cells positive for the respective surface CDs.

C3 and C4 components of complement was not particularly rewarding in this study.

The results obtained when testing the CRP and IL6 levels are of greater interest. Both tended to decrease following the therapy. The decrease was quite common in the case of IL-6, where it was highly significant. These data suggest that a reduction of IL- 6 levels might be quite a reliable marker of successful therapy. Moreover, because of its biological effects, that is, inhibition of p53-induced apoptosis [28] and suppression of phosphorylation of the retinoblastoma protein [29], its drop might contribute to the favorable course of the disease. Another favorable effect of IL-6 decrease might be associated with its role in STAT-3 activation. High levels of STAT-3 can prevent dendritic cell maturation and subsequent presentation of the antigens [30]. Thus, increased levels of IL-6 might exhibit an immunosuppressive effect. In a way, the present data correspond with the earlier observations indicating that IL-6 levels are raised in parallel with the progression of the disease into blastic phase [31, 32]. An association of remission with a decrease of CRP levels was less consistent. Although CRP levels dropped in all patients with increased levels detected in their sera taken prior to the start of the therapy, in four other patients a CRP increase was observed in the course of the observation period; in two of them it was only transitory. Because of the nature of this acute phase reactant [33-35], it is rather difficult to interpret the latter findings. In one of the patient the transitional rise of CRP was associated with a respiratory disease. In the other patients some undetected microinflammation processes might have been involved.

Possibly the most important among our findings are the changes of cell-mediated immunity parameters associated with the achievement of remission. They were represented by a markedly increased capability of stimulated CD3+ cells to produce cytokines. Since at the time of remission, the sum of percentages of $\mathrm{CD} 3+$ cells producing any of the cytokines tested exceeded 100 in most of the patients, it is possible to conclude that the changes observed were mainly due to an increase in cells producing more than one cytokine. Thus, a restoration of the Tcell activities associated with the suppression of the disease was observed. Similar results were reported by Reuben et al. [36]. and Guarini et al. [37]. in patients, in whom hematologic remission was achieved by INF $\alpha$ treatment. The mechanisms responsible for the present findings are not quite clear. In this respect, two previous in vitro studies may be of interest and provide a lead for further studies. Pawelec et al. [38]. have reported the production of the immunosuppressive IL-10 cytokine, a potent inhibitor of type 1 cytokines, by CML cells cultivated in vitro and have demonstrated that its neutralization by monoclonal antibody considerably enhanced the proliferation of lymphocytes in mixed lymphocyte/tumor cell cultures [38]. In another study, Kiani et al. [39]. Showed that CD4+ cells from CML patients, which had been separated from the leukemic cells, after stimulation produced type 1 cytokines in amounts comparable to those seen in normal subjects. Taken together, these two sets of data suggest that the products of CML cells may themselves be responsible for the reduced immunocompetence of the CD3+ cells. One point deserves a special comment. All ten patients, in whom the respective data were available, had been treated, at least for some time, with IM. This drug has been reported to suppress CD3+ cell activation in vitro $[40,41]$ as well as other parameters of Tcell immunity in vivo [42-44]. Our findings in the present study do not seem to be in agreement with those observations. One can therefore hypothesize that the alleviation of the CMLassociated processes, which was induced by the successful therapy, was a more important factor than the putative immunosuppressive effect of IM. Furthermore, it has recently been reported that IM is suppressing the activation and proliferation of $\mathrm{CD} 4+\mathrm{CD} 25+$ regulatory cells ( $\mathrm{T}_{\text {reg }}$ cells) which are producing strong immunosuppressive factors like IL-10, transforming growth factor $\beta$ (TGF $\beta$ ) and granzyme $B$ [45]. It is thus very well possible that in the patients studied the IM-induced suppression of $\mathrm{T}_{\text {reg }}$ contributed to the present observation. Unfortunately, we did not monitor the levels of $\mathrm{T}_{\text {reg }}$ cells in the present study. It should also be recalled that a significant increase of INF $\gamma$-producing Tcells following IM treatment has been reported by Aswald et al. [46]. 
TABLE 6: Intracellular cytokines production in activated CD3+ lymphocytes.

\begin{tabular}{|c|c|c|c|c|c|c|}
\hline No. & Therapy & IL-2 & TNFalfa & INF- $\gamma$ & IL-4 & CPI \\
\hline \multirow{7}{*}{ (1) } & $\mathrm{dg}, \mathrm{HU}$ & 56 & 44 & 12 & 4 & \\
\hline & IFN & 42 & 49 & 18 & 3 & \\
\hline & IFN & 31 & 35 & 23 & 5 & \\
\hline & IM & 53 & 60 & 30 & 2 & \\
\hline & IM & 61 & 48 & 36 & 3 & \\
\hline & IM & n.t. ${ }^{a}$ & n.t. & n.t. & n.t. & \\
\hline & DS & 32 & 60 & $23^{*}$ & 1 & 1.000 \\
\hline \multirow{7}{*}{ (2) } & $\mathrm{dg}, \mathrm{HU}$ & 31 & 53 & 62 & 2 & \\
\hline & IFN & 10 & 23 & 29 & 5 & \\
\hline & IFN & 69 & 66 & 30 & 4 & \\
\hline & IFN & 76 & 65 & 32 & 5 & \\
\hline & IM & 67 & 73 & 42 & 6 & \\
\hline & IM & n.t. & n.t. & n.t. & n.t. & \\
\hline & IM & 55 & 45 & 35 & $20 *$ & 1.047 \\
\hline \multirow{6}{*}{ (3) } & $\mathrm{dg}, \mathrm{HU}$ & 1 & 54 & 41 & 6 & \\
\hline & IFN & 24 & 46 & 36 & 3 & \\
\hline & IFN & 48 & 66 & 50 & 3 & \\
\hline & IM & 23 & 51 & 25 & 1 & \\
\hline & IM & n.t. & n.t. & n.t. & n.t. & \\
\hline & IM & 49 & 57 & 51 & 20 & 1.735 \\
\hline \multirow{5}{*}{ (4) } & dg, HU & 17 & 20 & 25 & 6 & \\
\hline & IFN & 31 & 46 & 29 & 8 & \\
\hline & IFN & 38 & 78 & 38 & 6 & \\
\hline & IM & n.t. & n.t. & n.t. & n.t. & \\
\hline & IM & $56^{* *}$ & 65 & $44^{* *}$ & 11 & 2.588 \\
\hline \multirow{6}{*}{ (5) } & dg, HU & 22 & 21 & 14 & 4 & \\
\hline & $\mathrm{HU}$ & 50 & 55 & 25 & 4 & \\
\hline & IFN & 39 & 50 & 30 & 2 & \\
\hline & IM & 37 & 49 & 24 & 8 & \\
\hline & IM & 52 & 58 & 30 & 2 & \\
\hline & IM & 38 & 41 & 30 & 5 & 1.869 \\
\hline \multirow{5}{*}{ (6) } & dg, IFN & 11 & 17 & 22 & 2 & \\
\hline & IFN & 36 & 51 & 32 & 3 & \\
\hline & IM & 48 & 55 & 35 & 5 & \\
\hline & DS & 20 & 59 & 45 & 3 & \\
\hline & DS & 18 & 44 & $37^{*}$ & 19 & 2.269 \\
\hline \multirow{5}{*}{ (7) } & dg, HU & 51 & 46 & 34 & 3 & \\
\hline & $\mathrm{HU}$ & 52 & 42 & 30 & 2 & \\
\hline & $\mathrm{HU}$ & 52 & 68 & 55 & 5 & \\
\hline & IM & n.t. & n.t. & n.t. & n.t. & \\
\hline & IM & 52 & 53 & 34 & 25 & 1.223 \\
\hline \multirow{6}{*}{ (8) } & dg, IM & 42 & 44 & 23 & 2 & \\
\hline & IM & 38 & 44 & 19 & 2 & \\
\hline & IM & 16 & 25 & 13 & 5 & \\
\hline & IM & n.t. & n.t. & n.t. & n.t. & \\
\hline & IM & n.t. & n.t. & n.t. & n.t. & \\
\hline & IM & 41 & 37 & 23 & 3 & 0.937 \\
\hline \multirow{3}{*}{ (9) } & $\mathrm{dg}, \mathrm{IM}$ & 2 & 34 & 45 & 1 & \\
\hline & IM & n.t. & n.t. & n.t. & n.t. & \\
\hline & IM & 31 & 74 & 57 & 13 & 2.134 \\
\hline
\end{tabular}


TABle 6: Continued.

\begin{tabular}{|c|c|c|c|c|c|c|}
\hline No. & Therapy & IL-2 & TNFalfa & INF- $\gamma$ & IL-4 & CPI \\
\hline \multirow{4}{*}{ (10) } & $\mathrm{dg}, \mathrm{IM}$ & n.t. & n.t. & n.t. & n.t. & \\
\hline & IM & 27 & 32 & 14 & 1 & \\
\hline & IM & 38 & 54 & 24 & 3 & \\
\hline & IM & $50^{* *}$ & 51 & $30^{* *}$ & $6^{* *}$ & 1.827 \\
\hline \multirow{3}{*}{ (11) } & $\mathrm{dg}, \mathrm{HU}$ & n.t. & n.t. & n.t. & n.t. & \\
\hline & DS & 59 & 62 & 23 & 1 & \\
\hline & DS & n.t. & n.t. & n.t. & n.t. & n.t. \\
\hline
\end{tabular}

CPI:Cytokine Production Index - a ratio between the sum of cytokine producing cells ls as detected in the last sample and the sum of cytokine producing cells in the first sample available.

${ }^{a}$ n.t.:not tested.

${ }^{*} P<.05,{ }^{* *} P<.01 . P$ for trend with time.

TABLE 7: Presence and geometric mean titres of antibodies against human herpesviruses in CML patients prior to the start of the therapy and after achieiving hematological and/or complete cytogenetic remission.

\begin{tabular}{|c|c|c|c|c|c|c|c|c|c|c|c|}
\hline \multicolumn{12}{|c|}{ Antibody presence } \\
\hline \multirow[t]{2}{*}{ Sample } & \multirow[t]{2}{*}{ No. } & \multicolumn{2}{|c|}{ HSV1/2 } & \multicolumn{2}{|c|}{ CMV } & \multicolumn{2}{|c|}{$\mathrm{VZV}$} & \multicolumn{4}{|c|}{ EBV } \\
\hline & & $\operatorname{IgG}$ & $\operatorname{IgM}$ & $\operatorname{IgG}$ & $\operatorname{IgM}$ & $\operatorname{IgG}$ & $\operatorname{IgM}$ & VCAIgG & VCAIgM & EAIgG & EBNA IgM \\
\hline First & 11 & 11 & 2 & 8 & 0 & 11 & 2 & 11 & 2 & 3 & 10 \\
\hline Last & 11 & 11 & 0 & 8 & 1 & 11 & 2 & 11 & 2 & 3 & 10 \\
\hline \multicolumn{12}{|c|}{ GMT } \\
\hline First & 11 & 8.12 & 0.65 & 1.83 & 0.47 & 2.83 & 0.74 & 7.41 & 0.33 & 0.57 & 4.28 \\
\hline Last & 11 & 8.33 & 0.57 & 2.01 & 0.47 & 2.61 & 0.54 & 8.20 & 0.34 & 0.65 & 4.79 \\
\hline
\end{tabular}

TABLE 8: Presence and geometric mean titres of antibodies against human papillomaviruses in CML patients prior to the start of the therapy and after achieving hematological and/or complete cytogenetic remission.

\begin{tabular}{|c|c|c|c|c|c|c|c|}
\hline \multicolumn{8}{|c|}{ Antibody presence } \\
\hline Sample & No. & HPV6 & HPV11 & HPV16 & HPV18 & HPV31 & HPV33 \\
\hline First & 11 & 6 & 5 & 3 & 3 & 3 & 1 \\
\hline Last & 11 & 5 & 3 & 3 & 3 & 2 & 1 \\
\hline \multicolumn{8}{|c|}{ GMT } \\
\hline First & 11 & 1.27 & 1.01 & 0.68 & 1.00 & 0.79 & 0.50 \\
\hline Last & 11 & 1.08 & 0.88 & 0.65 & 0.75 & 0.61 & 0.38 \\
\hline
\end{tabular}

Our attempts to find a reflection of these changes in the antibody titers against herpesviruses and papillomaviruses, two virus families known to be activated under immunosuppression, failed completely. As indicated in a previous paper [22], there were no significant differences in the prevalence of antibodies against these viruses between the untreated CML patients and matched normal control subjects. In the present study the antibody patterns in sera taken before the start of therapy and after achieving remission were comparable, this strongly suggesting that in the course of the observation period the activation of latent infections did not occur or could not be revealed by the antibody tests used.

In spite of inconsistency of the treatment regimens described above, some differences in the changes of the immunological parameters studied, which might have been associated with the drugs used, were recorded. Two observations are noteworthy. First, the autoantibodies were more frequently seen in patients who had been treated with HU and INF $\alpha$ than in those treated exclusively with TKI, and they tended to disappear after substituting TKI for HU and INF $\alpha$. Still, the lack of consistency and the small number of patients tested preclude any conclusions. Second, increase of NK cells was detected more frequently in those exclusively treated with TKI than in patients who had undergone combined therapy.

\section{Conclusions}

The present results indicate that the altered parameters of innate immunity found in the CML patients prior to the start of any therapy tended to normalize in the course of therapy leading to remission. Other data suggested, but did not prove, that some of the parameters monitored might be influenced by the treatment modality used. 


\section{Acknowledgments}

Supported by grants from the Internal Granting Agency of the Ministry of Health, Czech Republic (IGA MZCR NC/6957-3, and NR/9075-3) and by Research Project No. 000273 3601, Institute of Hematology and Blood Transfusion. The authors express their indebtedness to H. Tlaskalova for critical reading of the manuscript.

\section{References}

[1] M. Suehiro, S. Kishimoto, T. Wakabayashi et al., "Hydroxyurea dermopathy with a dermatomyositis-like eruption and a large leg ulcer," British Journal of Dermatology, vol. 139, no. 4, pp. 748-749, 1998.

[2] M. J. Dacey and J. P. Callen, "Hydroxyurea-induced dermatomyositis-like eruption," Journal of the American Academy of Dermatology, vol. 48, no. 3, pp. 439-441, 2003.

[3] M. Talpaz, K. B. McCredie, G. M. Mavligit, and J. U. Gutterman, "Leukocyte interferon-induced myeloid cytoreduction in chronic myelogenous leukemia," Blood, vol. 62, no. 3, pp. 689-692, 1983.

[4] M. Talpaz, K. McCredie, H. Kantarjian, J. Trujillo, M. Keating, and J. Gutterman, "Chronic myelogenous leukaemia: haematological remissions with alpha interferon," British Journal of Haematology, vol. 64, no. 1, pp. 87-95, 1986.

[5] F. Bonifazi, A. De Vivo, G. Rosti et al., "Chronic myeloid leukemia and interferon- $\alpha$ : a study of complete cytogenetic responders," Blood, vol. 98, no. 10, pp. 3074-3081, 2001.

[6] J. J. Molldrem, P. P. Lee, C. Wang et al., "Evidence that specific $\mathrm{T}$ lymphocytes may participate in the elimination of chronic myelogenous leukemia," Nature Medicine, vol. 6, no. 9, pp. 1018-1023, 2000.

[7] A. Burchert, S. Wölfl, M. Schmidt et al., "Interferon- $\alpha$, but not the ABL-kinase inhibitor imatinib (STI571), induces expression of myeloblastin and a specific T-cell response in chronic myeloid leukemia," Blood, vol. 101, no. 1, pp. 259-264, 2003.

[8] C. J. Wu, X.-F. Yang, S. McLaughlin et al., "Detection of a potent humoral response associated with immune-induced remission of chronic myelogenous leukemia," Journal of Clinical Investigation, vol. 106, no. 5, pp. 705-714, 2000.

[9] D. Chakrabarti, B. Hultgren, and T. A. Stewart, "IFN- $\alpha$ induces autoimmune $\mathrm{T}$ cells through the induction of intracellular adhesion molecule-1 and B7.2," Journal of Immunology, vol. 157, no. 2, pp. 522-528, 1996.

[10] D. Tosi, R. Valenti, A. Cova et al., "Role of cross-talk between IFN- $\alpha$-induced monocyte-derived dendritic cells and NK cells in priming $\mathrm{CD} 8+\mathrm{T}$ cell responses against human tumor antigens," Journal of Immunology, vol. 172, no. 9, pp. 53635370, 2004.

[11] S. Sacchi, H. Kantarjian, S. O’Brien, P. R. Cohen, S. Pierce, and M. Talpaz, "Immune-mediated and unusual complications during interferon alfa therapy in chronic myelogenous leukemia," Journal of Clinical Oncology, vol. 13, no. 9, pp. 2401-2407, 1995.

[12] E. Tóthová, A. Kafková, N. Štecová, M. Fričová, T. Guman, and E. Švorcová, "Immune-mediated complications during interferon alpha therapy in chronic myelogenous leukemia," Neoplasma, vol. 49, no. 2, pp. 91-94, 2002.

[13] M. W. N. Deininger, J. M. Goldman, and J. V. Melo, "The molecular biology of chronic myeloid leukemia," Blood, vol. 96, no. 10, pp. 3343-3356, 2000.
[14] H. Kantarjian, C. Sawyers, A. Hochhaus et al., "Hematologic and cytogenetic responses to imatinib mesylate in chronic myelogenous leukemia," New England Journal of Medicine, vol. 346, no. 9, pp. 645-652, 2002.

[15] B. J. Druker, M. Talpaz, D. J. Resta et al., "Efficacy and safety of a specific inhibitor of the BCR-ABL tyrosine kinase in chronic myeloid leukemia," New England Journal of Medicine, vol. 344, no. 14, pp. 1031-1037, 2001.

[16] V. Nardi, M. Azam, and G. Q. Daley, "Mechanisms and implications of imatinib resistance mutations in BCR-ABL," Current Opinion in Hematology, vol. 11, no. 1, pp. 35-43, 2004.

[17] M. E. Gorre, M. Mohammed, K. Ellwood et al., "Clinical resistance to STI-571 cancer therapy caused by BCR-ABL gene mutation or amplification," Science, vol. 293, no. 5531, pp. 876-880, 2001.

[18] N. P. Shah, C. Tran, F. Y. Lee, P. Chen, D. Norris, and C. L. Sawyers, "Overriding imatinib resistance with a novel ABL kinase inhibitor," Science, vol. 305, no. 5682, pp. 399-401, 2004.

[19] E. Weisberg, P. Manley, J. Mestan, S. Cowan-Jacob, A. Ray, and J. D. Griffin, "AMN107 (nilotinib): a novel and selective inhibitor of BCR-ABL," British Journal of Cancer, vol. 94, no. 12, pp. 1765-1769, 2006.

[20] P. S. Kim, P. P. Lee, and D. Levy, "Dynamics and potential impact of the immune response to chronic myelogenous leukemia," PLoS Computational Biology, vol. 4, no. 6, article no. e1000095, 2008.

[21] V. Vonka, "Immunotherapy of chronic myeloid leukemia: present state and future prospects," Immunotherapy, vol. 2, no. 2, pp. 227-241, 2010.

[22] Z. Humlová, H. Klamová, I. Janatková et al., "Immunologic profiles of patients with chronic myeloid leukemia. I. State before the start of treatment," Folia Biologica (Praha), vol. 52, no. 3, pp. 47-58, 2006.

[23] E. Hamšíková, V. Ludvíková, M. Šmahel, M. Sapp, and V. Vonka, "Prevalence of antibodies to human Papillomaviruses in the general population of the Czech Republic," International Journal of Cancer, vol. 77, no. 5, pp. 689-694, 1998.

[24] J. L. Steegmann, G. Moreno, C. Aláez et al., "Chronic myeloid leukemia patients resistant to or intolerant of interferon $\alpha$ and subsequently treated with imatinib show reduced immunoglobulin levels and hypogammaglobulinemia," Haematologica, vol. 88, no. 7, pp. 762-768, 2003.

[25] M. Nagasawa and S. Mizutani, "Selective effect of imatinib on serum IgM in a patient with CML," International Journal of Hematology, vol. 80, no. 4, pp. 381-382, 2004.

[26] A.-I. Kälsch, M. Soboletzki, W. H. Schmitt et al., "Imatinib mesylate, a new kid on the block for the treatment of antineutrophil cytoplasmic autoantibodies-associated vasculitis?" Clinical and Experimental Immunology, vol. 151, no. 3, pp. 391-398, 2008.

[27] D. Q. Minh, E. Czink, A. Mod, G. Fust, and S. R. Hollan, "Serial complement measurements in patients with leukaemia," Clinical and Laboratory Haematology, vol. 5, no. 1, pp. 23-34, 1983.

[28] E. Yonish-Rouach, D. Resnitzky, J. Lotem, L. Sachs, A. Kimchi, and M. Oren, "Wild-type p53 induces apoptosis of myeloid leukaemic cells that is inhibited by interleukin-6," Nature, vol. 352, no. 6333, pp. 345-347, 1991.

[29] D. Resnitzky, N. Tiefenbrun, H. Berissi, and A. Kimchi, "Interferons and interleukin 6 suppress phosphorylation of the retinoblastoma protein in growth-sensitive hematopoietic 
cells," Proceedings of the National Academy of Sciences of the United States of America, vol. 89, no. 1, pp. 402-406, 1992.

[30] S.-J. Park, T. Nakagawa, H. Kitamura et al., "IL-6 regulates in vivo dendritic cell differentiation through STAT3 activation," Journal of Immunology, vol. 173, no. 6, pp. 3844-3854, 2004.

[31] M. Anand, S. K. Chodda, P. M. Parikh, and J. S. Nadkarni, "Abnormal levels of proinflammatory cytokines in serum and monocyte cultures from patients with chronic myeloid leukaemia in different stages, and their role in prognosis," Haematological Oncology, vol. 16, no. 4, pp. 143-154, 1998.

[32] K. E. Panteli, E. C. Hatzimichael, P. K. Bouranta et al., "Serum interleukin (IL)-1, IL-2, sIL-2Ra, IL-6 and thrombopoietin levels in patients with chronic myeloproliferative diseases," British Journal of Haematology, vol. 130, no. 5, pp. 709-715, 2005.

[33] T. W. Du Clos and C. Mold, "C-reactive protein. An activator of innate immunity and a modulator of adaptive immunity," Immunologic Research, vol. 30, no. 3, pp. 261-277, 2004.

[34] A. J. Szalai, "C-reactive protein (CRP) and autoimmune disease: facts and conjectures," Clinical and Developmental Immunology, vol. 11, no. 3-4, pp. 221-226, 2004.

[35] R. Kleemann, P. P. Gervois, L. Verschuren, B. Staels, H. M. G. Princen, and T. Kooistra, "Fibrates down-regulate IL-1stimulated C-reactive protein gene expression in hepatocytes by reducing nuclear $\mathrm{p} 50-\mathrm{NF} \kappa \mathrm{B}-\mathrm{C} / \mathrm{EBP}-\beta$ complex formation," Blood, vol. 101, no. 2, pp. 545-551, 2003.

[36] J. M. Reuben, B. N. Lee, H. Johnson, H. Fritsche, H. M. Kantarjian, and M. Talpaz, "Restoration of Th1 cytokine synthesis by $\mathrm{T}$ cells of patients with chronic myelogenous leukaemia in cytogenetic and haematologic remission with interferon-alpha,", Clinical and Cancer Research, vol. 6, no. 5, pp. 1671-1677, 2000.

[37] A. Guarini, M. Breccia, E. Montefusco et al., "Phenotypic and functional characterization of the host immune compartment of chronic myeloid leukaemia patients in complete haematological remission," British Journal of Haematology, vol. 113, no. 1, pp. 136-142, 2001.

[38] G. Pawelec, A. Rehbein, E. Schlotz, and P. Da Silva, "Cellular immune responses to autologous chronic myelogenous leukaemia cells in vitro," Cancer Immunology Immunotherapy, vol. 42, no. 3, pp. 193-199, 1996.

[39] A. Kiani, I. Habermann, K. Schäkel, A. Neubauer, L. Rogge, and G. Ehninger, "Normal intrinsic Th1/Th2 balance in patients with chronic phase chronic myeloid leukemia not treated with interferon- $\alpha$ or imatinib," Haematologica, vol. 88, no. 7, pp. 754-761, 2003.

[40] R. Seggewiss, K. Loré, E. Greiner et al., "Imatinib inhibits Tcell receptor-mediated T-cell proliferation and activation in a dose-dependent manner," Blood, vol. 105, no. 6, pp. 2473 2479, 2005.

[41] A. B. Dietz, L. Souan, G. J. Knutson, P. A. Bulur, M. R. Litzow, and S. Vuk-Pavlović, "Imatinib mesylate inhibits Tcell proliferation in vitro and delayed-type hypersensitivity in vivo," Blood, vol. 104, no. 4, pp. 1094-1099, 2004.

[42] J. J. Gu, N. Zhang, Z. W. He, A. J. Koleske, and A. M. Pendergast, "Defective T cell development and function in the absence of Abelson kinases," Journal of Immunology, vol. 179, no. 11, pp. 7334-7343, 2007.

[43] P. Sinai, R. E. Berg, J. M. Haynie, M. J. Egorin, R. L. Ilaria Jr., and J. Forman, "Imatinib mesylate inhibits antigen-specific memory CD8 T cell responses in vivo," Journal of Immunology, vol. 178, no. 4, pp. 2028-2037, 2007.
[44] S. Mumprecht, M. Matter, V. Pavelic, and A. F. Ochsenbein, "Imatinib mesylate selectively impairs expansion of memory cytotoxic $\mathrm{T}$ cells without affecting the control of primary viral infections," Blood, vol. 108, no. 10, pp. 3406-3413, 2006.

[45] J. Chen, A. Schmitt, K. Giannopoulos et al., "Imatinib impairs the proliferation and function of CD4+CD25+ regulatory $\mathrm{T}$ cells in a dose-dependent manner," International Journal of Oncology, vol. 31, no. 5, pp. 1133-1139, 2007.

[46] J. M. Aswald, J. H. Lipton, S. Aswald, and H. A. Messner, "Increased IFN- $\gamma$ synthesis by $\mathrm{T}$ cells from patients on imatinib therapy for chronic myeloid leukemia," Cytokines, Cellular and Molecular Therapy, vol. 7, no. 4, pp. 143-149, 2002. 


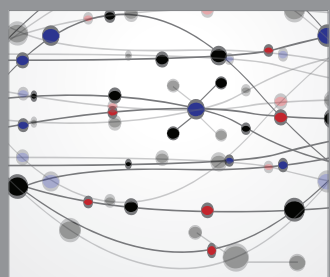

The Scientific World Journal
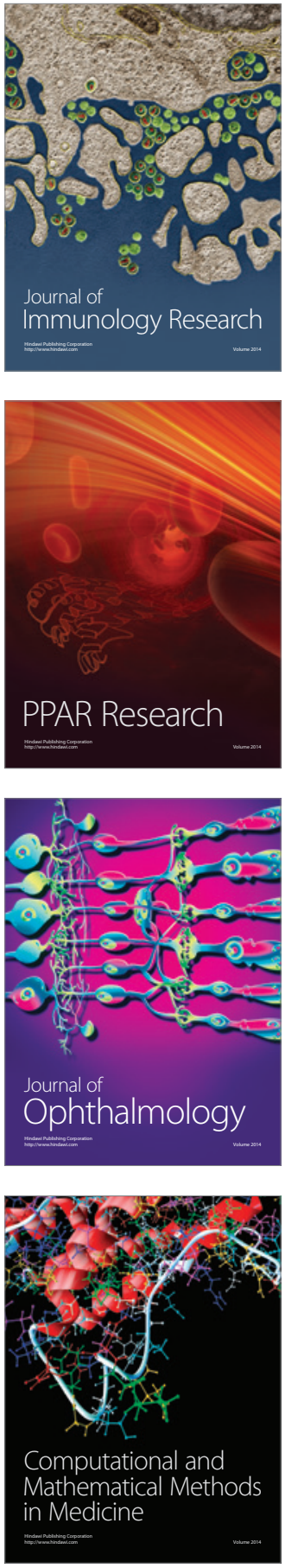

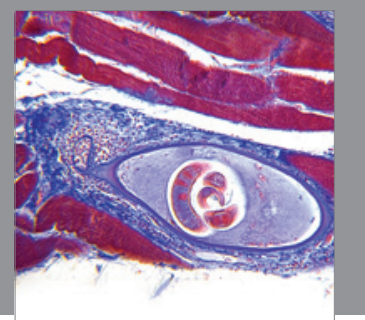

Gastroenterology

Research and Practice
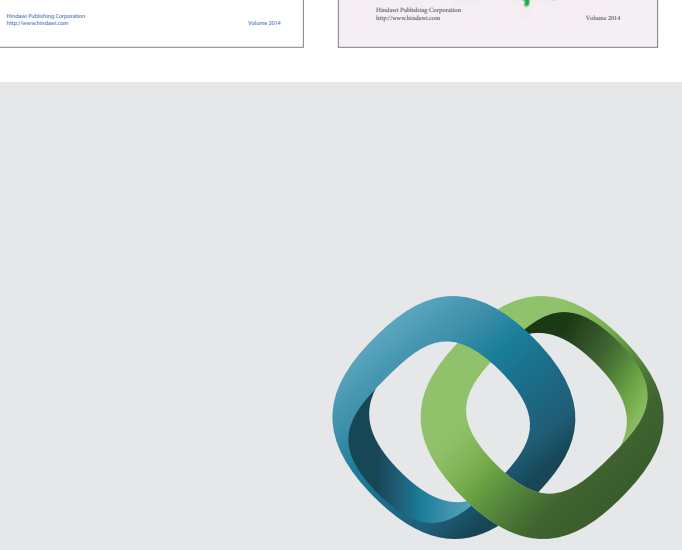

\section{Hindawi}

Submit your manuscripts at

http://www.hindawi.com
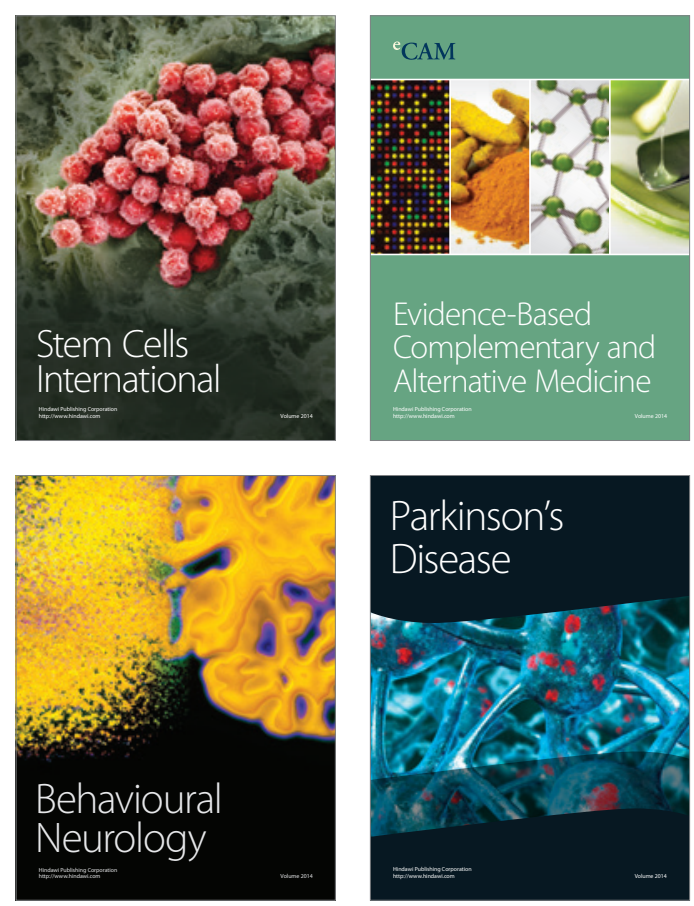

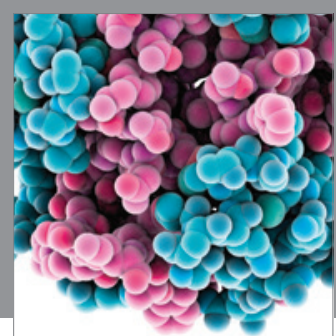

Journal of
Diabetes Research

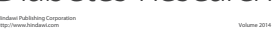

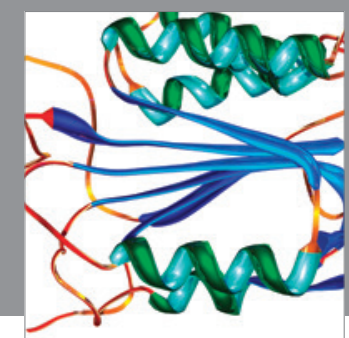

Disease Markers
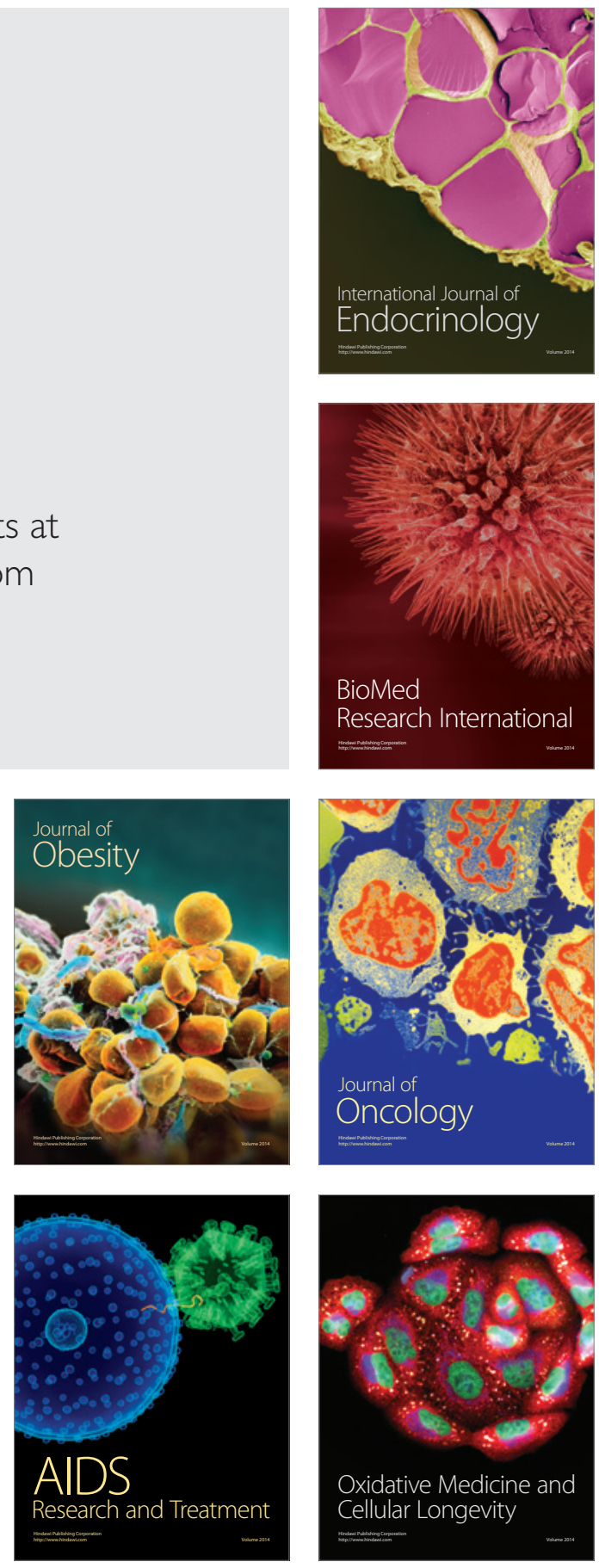